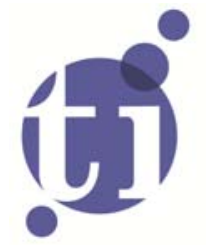

\title{
Measuring Pattern, Amplitude and Timing Differences between Monetary and Non- Monetary Seasonal Factors of Tourism - The Case of Aruba
}

Jorge Ridderstaat ${ }^{1}$ Peter Nijkamp2

1 Centrale Bank van Aruba, J.E. Oranjestad, Aruba, Dutch Caribbean;

2 Faculty of Economics and Business Administration, VU University Amsterdam, and Tinbergen Institute. 
Tinbergen Institute is the graduate school and research institute in economics of Erasmus University Rotterdam, the University of Amsterdam and VU University Amsterdam.

More TI discussion papers can be downloaded at http://www.tinbergen.nl

Tinbergen Institute has two locations:

Tinbergen Institute Amsterdam

Gustav Mahlerplein 117

1082 MS Amsterdam

The Netherlands

Tel.: +31(0)205251600

Tinbergen Institute Rotterdam

Burg. Oudlaan 50

3062 PA Rotterdam

The Netherlands

Tel.: +31(0)10 4088900

Fax: $+31(0) 104089031$

Duisenberg school of finance is a collaboration of the Dutch financial sector and universities, with the ambition to support innovative research and offer top quality academic education in core areas of finance.

DSF research papers can be downloaded at: http://www.dsf.nl/

Duisenberg school of finance

Gustav Mahlerplein 117

1082 MS Amsterdam

The Netherlands

Tel.: +31(0)20 5258579 


\title{
Measuring Pattern, Amplitude and Timing Differences between Monetary and Non-Monetary Seasonal Factors of Tourism - The Case of Aruba
}

\author{
Jorge Ridderstaat ${ }^{1}$ \\ Centrale Bank van Aruba, \\ J.E. Irausquin Boulevard 8, \\ Oranjestad, Aruba, Dutch Caribbean \\ Fax: (297) 5252159 \\ E-mail: ridderstaatjr@setarnet.aw \\ Peter Nijkamp \\ Tinbergen Instituut \\ Email: pnijkamp@vu.nl
}

\begin{abstract}
Seasonality is a frequent and important occurrence in the tourism industry, with simultaneous effects on both the volume and financial flows of tourism. The seasonal characteristics of these monetary and nonmonetary tourism indicators can show diverging paths. Lack of synchronization between the seasonal patterns of these two types of indicators of tourism development can produce suboptimal situations, with less than best choices when formulating and implementing anti-seasonal policies. The purpose of this study is to measure pattern, amplitude and timing differences between the seasonal factors of monetary and non-monetary indicators of tourism development in Aruba. The study contributes to the gap in the literature on the dynamics in the co-movement of these two types of seasonal factors, while concurrently incorporating three measurement dimensions of this relation. Moreover, the study introduces novel calculation techniques in two of the three measurement dimensions. The methodology involves decomposing time series on both monetary and non-monetary variables using Census X12-ARIMA, with subsequent calculation of Pearson's correlation coefficients, median relative differences, and median timing differentials. The results show important quarterly differences in pattern, amplitude and timing of the seasonal factors, in terms of the applied timeframe, periodicity, variables and markets involved. The findings implicate the need for synchronizing strategies and a differentiated anti-seasonal policy.
\end{abstract}

Keywords: seasonality, Aruba, seasonal patterns, amplitude, timing, monetary and non-monetary tourism indicators

JEL classification: O11; C13; O29; Y10; Z18

Pn608jr

\footnotetext{
${ }^{1}$ The views expressed in this paper do not necessarily reflect those of the Central Bank of Aruba.
} 


\section{Introduction}

Seasonality is a concept frequently encountered in the tourism industry. It is one of the most problematic issues facing tourism, yet it is one of the least understood aspects of this business (Jang, 2004). Its importance crosses over from the academic literature to the domains of policy making and practical tourism management (Koenig-Lewis \& Bischoff, 2005; De Cantis et al., 2011). Butler (2001) defines seasonality as “...a temporal imbalance in the phenomenon of tourism, which may be expressed in terms of dimensions of such elements as numbers of visitors, expenditure of visitors, traffic in highways and other forms of transportation, employment and admissions to attractions." (p. 5).

According to Hylleberg (1992), the causes of seasonality can be convened into three groups, i.e., weather (e.g., variations in temperature, rainfall, snowfall, sunlight, daylight, etc.), calendar effects (e.g., timing of religious events such as Christmas, Easter, etc.), and timing decisions (e.g., school vacation). From the perspective of tourism, Butler (2001) distinguishes between institutional seasonality (resulting from religious, cultural, ethnic and social behavior of humans) and natural seasonality (which has to do with regular temporal and recurring variations in natural phenomena, for example, the climate). The typologies of both authors have common linkages with each other (e.g., weather seasonality with natural seasonality), which boils down to the seasonal phenomenon being a combination of both man-made and natural events.

There are numerous effects ascribed to seasonality, and understanding these impacts is critical for the tourism industry because seasonal variations can affect destination image, destination choice, and tourists' decisions on spending (Goh, 2012). Periodical swings in the flow of tourists, for example, produce situations of over-capacity, non-utilization of infrastructure, decrease in the work force and absence of investments during low seasons (Pegg et al., 2012), causing reduced profitability and productivity (Karamustafa \& Ulama, 2010). On the other hand, peak seasons of tourist flows can be characterized by over-use of public utilities

(e.g., water supply, waste management, and road use), causing dissatisfaction with residents and tourists alike, while the environment can irreversibly suffer from damages because of tourism pressures (Cuccia \& Rizzo, 2011). These effects may explain why there has been considerable efforts from both the public and private sectors to attempt to reduce seasonality in destination areas (Cannas, 2012). But, the literature shows as well that seasonality not always has a negative influence. For example, the environment needs a period of time to recover from heavy usage 
during peak seasons (Pegg et al., 2012), while maintenance work on buildings and attractions can be better done during off-peak periods (Cannas, 2012). It is, however, generally recognized that seasonality has more negative effects, particularly from a socio-economic perspective (Karamustafa \& Ulama, 2010). In any case, identifying the seasonal model affecting a destination's tourism is necessary to better understand and cope with the recurring developments in tourism.

Three important weaknesses have been identified in the literature on tourism seasonality. Firstly, the literature has mostly compared seasonality between non-monetary indicators of tourism development (e.g., comparing seasonality of visitors from different countries of origin), with much less emphasis on seasonal relations between monetary and non-monetary indicators. Seasonality is not an isolated event, but occurs in both physical and financial facets of tourism development. Each type of indicator has its own prominence for the tourism industry. For example, monetary indicators could be important for profitability of businesses and the generation of foreign exchange for destinations. Non-monetary indicators, such as number of visitors, on the other hand, may be important for job stability (e.g., the more visitors there are during each time of the year, the more people are continuously needed to adequately serve them). The comparison between monetary and non-monetary tourism seasonal factors could be important for when considering anti-seasonal policies. The literature on this type of policy (see for example Yacoumis, 1980; Koenig-Lewis \& Bischoff, 2010; Cannas, 2012) has been particularly geared towards finding solutions for the physical side of tourism seasonality (e.g., attracting more visitors or lowering them during certain periods) with much less consideration for the role of financial traits in seasonality. The latter could, for example, present undesirable consequences for the revenue management goals of businesses. Secondly, differences in seasonality between monetary and non-monetary tourism indicators can occur because of dissimilarities in patterns, levels of seasonal intensities as well as timing inconsistencies (e.g., seasonal peaks occuring earlier in one variable compared to the other). The literature has considered combinations of two of these measurement approaches (e.g., Dracatos, 1987; KoenigLewis \& Bischoff, 2005; Croce \& Wöber, 2010), but as far as is known, no study has considered all three lines of measurement together. Thirdly, when analyzing tourism seasonality using time series, the recurring periodic variations are best recognized and evaluated when eliminating other factors, such as trend and incidental elements. A number of authors have emphasized the 
available tools to quantify seasonality (e.g., Bender et al., 2005; Koenig-Lewis \& Bischoff, 2005; De De Cantis \& Ferrante, 2011; Cantis et al., 2011), where popular methods such as the Gini coefficient, the coefficient of variation, and the seasonal index have been analyzed. However, the literature has spent little attention on the diagnostics of the calculated seasonal factors and whether these are immediately suitable for comparisson in analyses, with possible biased conclusions in tourism seasonality studies.

The purpose of this paper is to compare the discrepancies in the seasonal factors of monetary and non-monetary indicators of tourism development in Aruba, in terms of patterns, amplitude and timing differences. The methodology involves decomposing time series on both monetary and non-monetary variables using Census X12-ARIMA, with subsequent calculation of Pearson's correlation coefficients, median relative differences, median variances, and median timing differentials. Understanding differences in seasonality between both monetary and nonmonetary tourism indicators could provide policy makers and practitioners of tourism (revenue) management with crucial information on how to design the appropriate mix of measures to simultaneously cope with the seasonal phenomenon in both these types of indicators of tourism development.

This study allows for a triad of contributions to the literature. Firstly, the study compares seasonality of both monetary and non-monetary factors, which has received little attention in the literature. The proposed research contributes to this literature gap by improving the understanding on the dynamics of the co-movement of seasonal factors of monetary and nonmonetary indicators of tourism. Secondly, the study simultaneously explores three dimensions of seasonality, which is most likely a novel approach. Also, the study proposes original methods for measuring both amplitude and timing differences between seasonal factors of monetary and nonmonetary tourism indicators. Thirdly, the study contributes as well to the literature on seasonality in small open island economies such as the case of Aruba.

The rest of this paper is organized as follows. Section two presents an overview of the literature covering the empirical relation between seasonal factors in tourism. Section three discusses tourism development in Aruba over the past decades. Section four reviews the data and the applied methodology, while section five presents the empirical results. Section six concludes and offers policy implications and lines for future research. 


\section{Literature Review}

The tourism literature has considered the seasonality phenomenon from several angles of approach. For example, Ashworth \& Thomas (1999), Dritsakis (2008) and Karamustafa \& Ulama (2010) have looked at how seasonality varied during the year, using one of more methods to measure this phenomenon. A second group of studies (Goh \& Law, 2002; Kulendran \& Wong, 2005; Lim et al., 2009; Vergori, 2012) departed from a forecasting perspective, whereby they looked at several models for forecasting tourism demand, with a relevant role laid out for seasonality. Another cluster in the tourism literature has looked at seasonality as an impacted or impacting factor (e.g., Lim \& McAleer, 2000; Yu et al., 2009, 2010; Hadwen et al., 2011; Boffa \& Succurro, 2012; Goh, 2012; Pegg et al., 2012). For example, Yu et al. (2010) found that the seasonal factor of weather conditions impacted those of demand for two parks in the United States. Alternatively, authors such as Yacoumis (1980), Baum \& Hagen (1999), Sharpley (2003), Jang (2004), Koenig-Lewis \& Bischoff (2005) and Cannas (2012) looked at the formulation and implementation of anti-seasonal policies to contain seasonal effects. An extended faction in the seasonality literature has considered seasonality by comparing seasonal differences of particularly tourism demand data (Drakatos, 1987; Donatos \& Zairis, 1991; Fernández-Morales, 2003; Bender et al., 2005; Koenig-Lewis \& Bischoff, 2002; Ahas et al., 2007; Koc \& Altinay, 2007; Croce \& Wöber, 2010; De Cantis \& Ferrante, 2011; De Cantis et al., 2011). For example, Drakatos (1987) compared the monthly seasonal patterns of arrivals to Greece from several destinations (including Austria, Italy, France, United Kingdom, Yugoslavia and US) for the period 1980-1985, and found considerable differences between the seasonal patterns of the nationalities arriving in Greece. Lim \& McAleer, (2000) compared the seasonal patterns of tourism arrivals from Hong Kong, Malaysia and Singapore to Australia, and noted considerable differences between the seasonal patterns of these three tourism-generating countries.

There is no general agreement as to which data should be used to measure and analyze seasonality (Koenig-Lewis \& Bischoff, 2005). Tourism demand in the studies comparing seasonality has been represented by variables such as tourist arrivals (Drakatos, 1987; Lim \& McAleer, 2000; Bender et al., 2005), average spending per person (Koc \& Altinay, 2007), hotel nights (Fernández-Morales, 2003), bednights (Croce \& Wöber, 2010) and hotel bed occupancy rates (De Cantis \& Ferrante, 2011; De Cantis et al., 2011). These variables are often linked to international demand for the destination studied, although in some instances (e.g., De Cantis \& 
Ferrante, 2011; De Cantis et al., 2011) domestic demand has also been included in the analysis. With the exception of Koc \& Altinay (2007), these studies have alsmost exclusively been based on comparing the seasonality of non-monetary indicators. The latter authors perhaps come closest in terms of analyzing the differences in seasonal patterns of both monetary and nonmonetary indicators of tourism development by investigating seasonal variations in monthly per person tourist spending in Turkey. For this purpose, they collected monthly data (January 1992December 2004) on tourist arrivals and tourism receipts, which they subsequently used to calculate the average spending per tourist. Their findings suggest that the seasonal pattern in per person tourist spending was considerably different from the seasonal pattern of tourist arrivals and tourism receipts. On itself, this is an interesting conclusion that adds credence to the idea of comparing seasonal factors of both monetary and non-monetary indicators.

Analyzing seasonality requires the ability to adequately quantify this phenomenon. Yet, there are no general general guidelines how to measure seasonality (Koenig-Lewis \& Bischoff, 2005). The methodologies applied in calculating and analyzing the seasonal patterns vary from study to study. For example, Bender et al. (2005) applied several measures of seasonality, including seasonality ratio and Gini coefficient, combined with bi-variate Pearsons correlation to gauge and evaluate seasonality. Koenig-Lewis \& Bischoff (2002) used a multiplicative model of seasonal decomposition (whereby the seasonal factor was determined as the difference between the actual and the average value), and different measurement techniques, including concentration indices, Gini coefficients, amplitude rations and indices of similarity to analyze the seasonality. Croce \& Wöber (2010) calculated the average bednights of 20 European city destinations as a proxy for the seasonal patterns, and subsequently applied Gini coefficients and Pearson's bivariate correlation coefficients to make seasonal comparissons. The methodological differences were also determinant for whether variations in seasonality were fixed for the whole period of analysis (e.g., Drakatos, 1987; Bender et al., 2005), or varied over the course of time (e.g., Koenig-Lewis \& Bischoff, 2002; Koc \& Altinay, 2007; De Cantis \& Ferrante, 2011; De Cantis et al., 2011).

Most of the studies were geared towards analyzing differences in seasonal patterns, and in some instances (Koenig-Lewis \& Bischoff, 2005; Croce \& Wöber, 2010), both patterns and amplitude differences were analyzed. None of the studies have considered examining differences in timing between the seasonal factors, which is considered an omission in these studies. 
While all studies found important differences in seasonality, there are three key methodological drawbacks found in the analyzed literature. Firstly, except for some exceptions like the rigorous work by Koc \& Altinay (2007), Dritsakis (2008) and Vergori (2012), little attention has been given to the issue of whether the seasonal factors were deterministic or stochastic in nature. This distinction is important because stochastic seasonal series have long memory, whereby shocks will last forever and may actually permanently change the seasonal pattern (Hylleberg et al., 1990). According to Beaulieu \& Miron (1993), the investigation of seasonal unit roots logically precedes the examination of other kinds of seasonality, because the latter can produce spurious results if seasonal unit roots are present but unaccounted for. Secondly, many of the studies did not provide any diagnostics on either the presence of seasonality, or the calculated seasonal patterns themselves. One can, for example, not determine the quality of the calculated seasonal data in these investigations. Lack of qualitatively adequate seasonal factors can produce biased results in the analysis of seasonality. Thirdly, the reviewed literature is particularly silent on comparing seasonal patterns in the same unit of analysis. Analyzing data with the same unit features is a precondition to avoid biased comparisons. The unit problem can be circumvented by standardizing the seasonal factors before starting with the comparison process. Considering these methodological downsides can improve the reliability of the results in the end, and will be considered in the further course of this study.

\section{Tourism and Seasonality in Aruba}

Aruba is a small island located about $32 \mathrm{~km}$ from the Northern coast of Venezuela. It has an area of $180 \mathrm{~km}^{2}$ (or about $1 \frac{1}{2}$ times the surface area of Walt Disney World in Orlando, Florida), and a population of about 100,000 people. Tourism has been a source of income for more than fifty years. The industry started to get grip in 1959, when the island built its first 100-room hotel, modeled after similar ones in Florida and Puerto Rico (Cole \& Razak, 2009). However, for a long time, the tourism industry played only a small role in the overall economic development of Aruba, given the dominant position of an oil refinery, the Lago Oil \& Transport Company, Ltd. (Vanegas \& Croes, 2000). The situation changed in 1985, when the oil refinery closed its doors, causing a shock to the Aruban economy. At that time, the refinery contributed to about $25 \%$ of Aruba's gross domestic product (GDP), and directly and indirectly employed between 30\%-40\% 
of Aruba's population (Ridderstaat, 2007). Moreover, it provided about 50\% of the foreign exchange earnings of the island and contributed to about $40 \%$ of all tax earnings.

The detrimental situation made finding a new source of economic activity a top priority. The most obvious way to increase income and foreign exchange receipts was to expand the tourism industry (Ridderstaat, 2007). Soon, new hotels, shopping malls and other commercial buildings were rising from the ground. The number of hotel rooms more than tripled, from 2,524 in 1986 to 7,975 in 2011. The efforts paid off: the number of stay-over visitors grew from 181,211 in 1986 to 871,316 in 2011. Tourism receipts grew from US\$ 157.2 million in 1986 to US\$1,340.8 million in 2011.

Today, tourism is the mainstay of the Aruban economy. According to the World Travel and Tourism Council (2012), tourism accounted for about 2/3 of the total GDP and employment in 2011. The United States is by far the largest market for Aruba, accounting on average for $65.4 \%$ of all stay-over visitors between 1996 and 2011. The Venezuelan market is the second largest market for Aruba (average 12.2\% between 1996 and 2011). Together, these two countries accounted on average for about 77.6\% of all stay-over visitors to Aruba between 1996 and 2011 . Other smaller markets include, among others, Colombia, the Netherlands, Canada, Argentina and Brazil.

Seasonality in Aruba's tourism is likely to be based predominantly on fundamentals external to the island. Weather conditions in Aruba are less volatile than in, for example, countries with four weather seasons, like the United States. The island is located in an area called the Southern Caribbean Dry Zone, with a discernible dry and rainy season, and sustained moderate to fresh easterlies (Meterorological Department of Atruba, 2013). Aruba has clear skies and bright sunshine almost every day of the year, with an average air temperature around 27.8 degrees (Aruba Tourism Authority, 2013). This makes local weather perhaps less influential on the seasonal tourism demand from various markets. According to Croes (2007), seasonality in tourism demand from the U.S. is probably influenced by institutional factors (e.g., school holdidays, Christmas) and the weather in that country (particularly the winters season). In the case of demand from the Latin American market, this may generally be affected by weather conditions in the country of origin itself (both winter and summer periods). In the specific case of Venezuela, which has mostly similar climate conditions as in Aruba, other seasonal influences, such as school vacations, the Holy Week, and Christmas may be the most 
determining factors in the seasonality of demand from this market. Hotels in Aruba may also influence the seasonal demand from those tourists with less hefty budgets, i.e., by pricing their room according to the season, whereby high season prices can outbalance the low season ones by up to $40 \%$ (Croes, 2007). In this way, domestic seasonal factors can steer to some extent the seasonality of demand from this specific group of tourists.

\section{Data and Methods}

This study is conceptually defined according to the framework presented in Figure 1, where the seasonal factors of the monetary indicators of tourism are compared with those of the nonmonetary indicators. The monetary indicators are proxied by the variables tourism expenditures and average daily expenditures. The study employs these two types of revenue indicators to test for the robustness of the findings. Both variables are included in aggregate form (respectively, TOUREXP_TOT and ADE_TOT) and are further segmented into the US, Venezuelan and other tourism markets (respectively TOUREXP_USA, TOUREXP_VEN, TOUREXP_OTH, ADE_USA, ADE_VEN, and ADE_OTH). The US and Venezuelan markets are included separately, given their relatively importance in Aruba's stay-over tourism (the latter is defined here as tourists remaining for 1 night or longer on the island). The other markets segment includes all other tourism markets (Colombia, the Netherlands, Canada, Argentina, Brazil, etc.). The data on the monetary indicators are derived from the periodical survey of the Central Bureau of Statistics of Aruba, and cover the period of the first quarter 1996 up to and including the fourth quarter of 2011. 


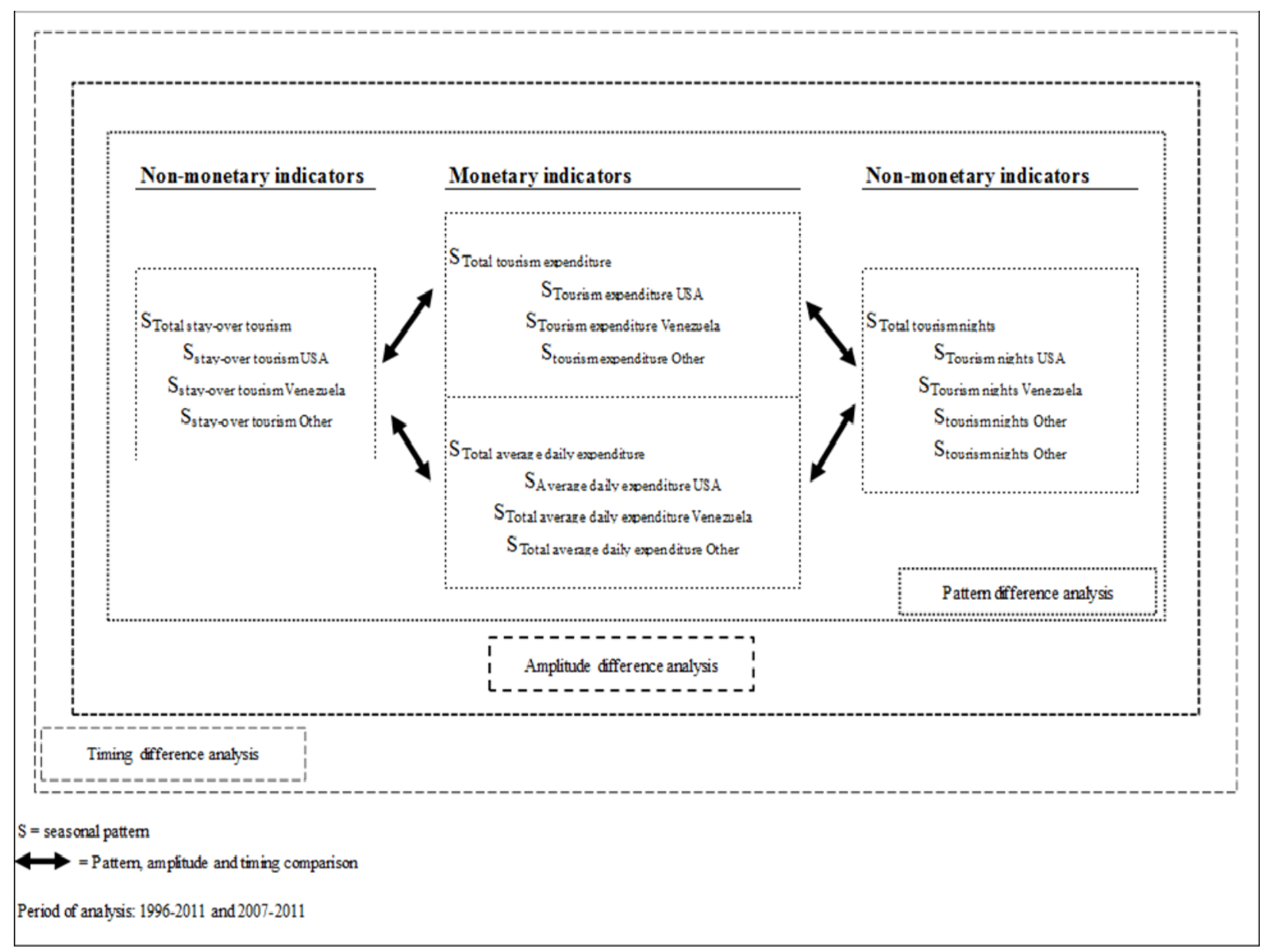

Fig. 1: Conceptual framework of the analysis of the seasonality relation between monetary and non-monetary indicators of tourism development

The non-monetary statistics (number of stay-over visitors, and visitors' nights) are also segmented into a total, US; Venezuela and others components (respectively STAYVIS_TOT, STAYVIS_USA, STAYVIS_VEN, STAYVIS_OTH, NIGHTS_TOT, NIGHTS_USA, NIGHTS_VEN, NIGHTS_OTH). Again, two types of non-monetary indicators are included in this study to test for the robustness of the outcomes. The data here are derived from the Central Bank of Aruba. In order to further test for the stability of the results, we have also included the period 2007-2011 in the analysis. So, basically, robustness in this study is assessed by applying different variables to represent both monetary and non-monetary indicators, and by applying different periods of analysis. Table 1 presents an overview of the variables involved in the study, where we transformed the variables into log function to stabilize their variance (Farooque, 2003). The table includes as well a number of descriptive statistics of the variables, i.e., the mean, median, maximum and minimum values as well as the coefficient of variation. The mean and 
median values of all variables are fairly close to each other, and, in some instances even identical. This implicates the absence of outliers, as can be seen by the small differences between the minimum and the maximum values, and the relatively low coefficients of variation.

\begin{tabular}{|c|c|c|c|c|c|c|c|}
\hline Variable & Description & Mean $\mathrm{T}$ & Median & Maximum & Minimum & $\begin{array}{l}\text { Standard } \\
\text { deviation }\end{array}$ & $\begin{array}{r}\text { Coefficient } \\
\text { of variation } \\
\text { (in \%) }\end{array}$ \\
\hline LSTAYMS_TOT & Logarithmof the total number of stay-over visitors & 12.1 & 12.1 & 12.3 & 11.9 & 0.1 & 0.9 \\
\hline LSTAYYS_USA & Logarithmof the number of stay-over visitors from the US market & 11.7 & 11.7 & 12.0 & 11.2 & 0.2 & 1.4 \\
\hline LSTAYYS_VEN & Logarithmof the number of stay-over visit ors from the Venezuelan market & 9.9 & 9.9 & 10.8 & 9.0 & 0.4 & 4.5 \\
\hline LSTAYMS_OTH & Logarithmof the number of stay-over visit ors from the other markets & 10.6 & 10.6 & 11.0 & 10.2 & 0.2 & 1.9 \\
\hline LNGHTS_TOT & Logarithmof total nights stayed by all stay-over visitors & 14.1 & 14.1 & 14.4 & 13.8 & 0.1 & 0.9 \\
\hline LNGHTS_USA & Logarithmof total nights stayed by stay-over visitors from the USA & 13.3 & 13.6 & 14.0 & 11.6 & 0.8 & 5.7 \\
\hline LNGHTS_VEN & Loganithmof total nights stayed by stay-over visitors from Venezuela & 11.4 & 11.5 & 12.6 & 9.0 & 0.9 & 7.7 \\
\hline LNGHTS_OTH & Logarithmof total nights stayed by stay-over visitors from the other markets & 13.1 & 12.9 & 14.3 & 12.5 & 0.5 & 3.9 \\
\hline LTOUREXP_TOT & Logarithmoftotal expenditures made in Aruba by all stay-over visitors & 11.9 & 11.9 & 12.3 & 11.6 & 0.1 & 1.1 \\
\hline LTOUREXP_USA & Logarithmoftotal expenditures made in Aruba by stay-over visitors of the USA & 11.4 & 11.5 & 12.0 & 10.9 & 0.2 & 2.0 \\
\hline LTOUREXP_VEN & Logarithmof total expenditures made in Aruba by stay-over visitors of Venezuela & 9.9 & 9.9 & 10.7 & 9.1 & 0.4 & 4.3 \\
\hline LTOUREXP_OTH & Logarithmof total expen ditures made in Arub a by stay-over visitors of the other markets & 10.5 & 10.4 & 11.0 & 10.1 & 0.2 & 1.7 \\
\hline LADE_TOT & Logarithmof total average daily expenditures & 4.7 & 4.7 & 5.0 & 4.4 & 0.1 & 2.5 \\
\hline LADE_USA & Loganithmof average daily expenditures by visit ors fromthe USA & 4.7 & 4.6 & 4.9 & 4.4 & 0.1 & 2.5 \\
\hline LADE_VEN & Logarithmof average daily expenditures by visitors from Venezuela & 5.0 & 5.0 & 5.5 & 4.6 & 0.2 & 3.9 \\
\hline LADE_OTH & Logarithmof average daily exp enditures by visitors fromthe other markets & 4.0 & 4.2 & 4.8 & 0.8 & 0.6 & 13.9 \\
\hline
\end{tabular}

Note: the coefficient of variation is equal to the ratio between the the stand ard deviation and the mean

To get a first impression of the seasonal differences between the monetary and non-monetary tourism indicators, we calculated first the quarterly ratios of each indicator in their annual total. Subsequently, we calculated the median values of these ratios per quarter, and subtracted then $25 \%$ from the results. The $25 \%$ is a proxy for the case when there is no seasonal factor influencing the quarterly results, where under normal conditions the ratio would be $25 \%$ for each quarter. The remaining values after subtraction provide a preliminary indication of the seasonal factors. Combinations of both monetary and non-monetary seasonal factors are presented in Charts 1-4, for both the periods 1996-2011 and 2007-2011. All charts show variations between the corrected ratios of both monetary and non-monetary seasonal factors, for all quarters. These differences are noticeable not only between the periods of analysis (1996-2011 versus 20072011), but also between quarters. This means that the further analysis of the differences should also consider a quarterly approach. 


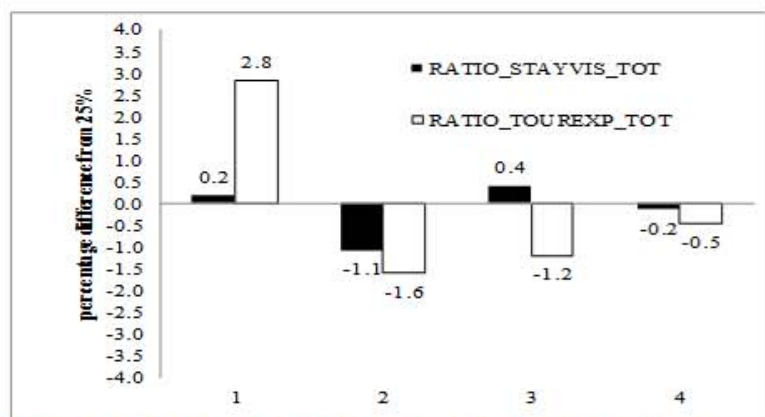

Chart la: Quarterly ratios between total tourism expenditures and total s tay-over (1996-2011)

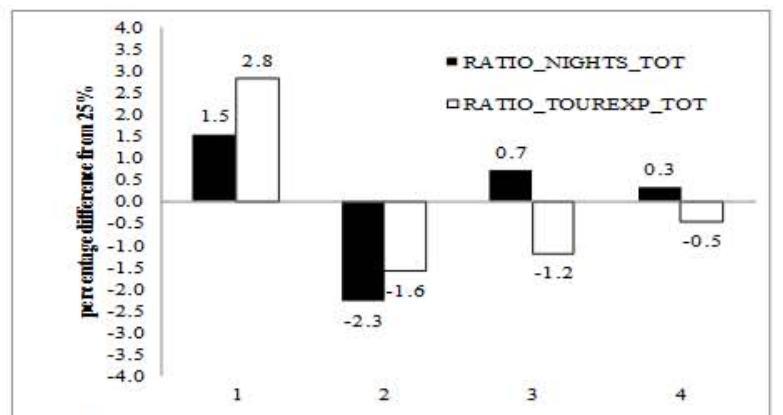

Chart 2a: Quarterly ratios between total tourism expenditures and total touris m nights (1996-2011)

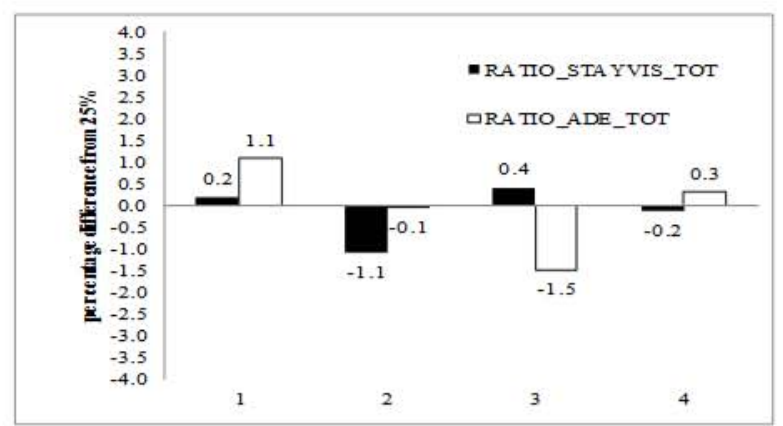

Chart 3a: Quarterły ratios between total average daily expenditure and total stay-over tourism (1996-2011)

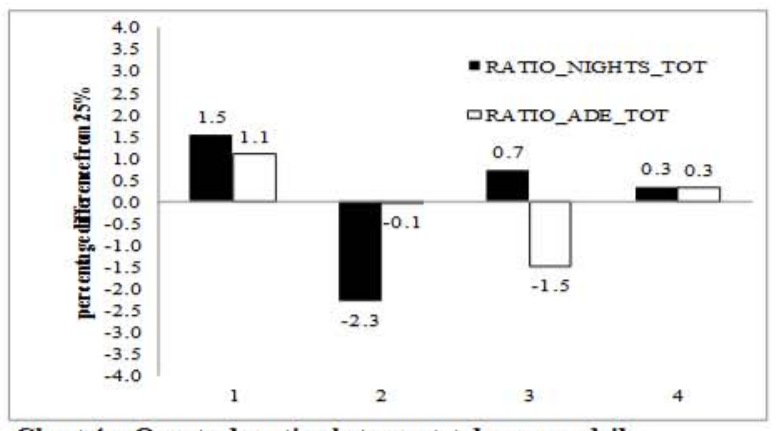

Chart 4a: Quarterly ratios between total average daily expenditure and total touris m nights (1996-2011)

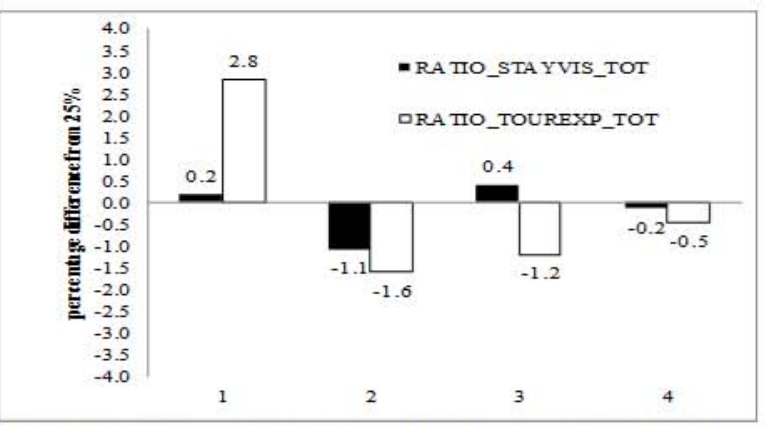

Chart 1b: Quarterly ratios between total touris $m$ expenditures and total stay-over (2007-2011)

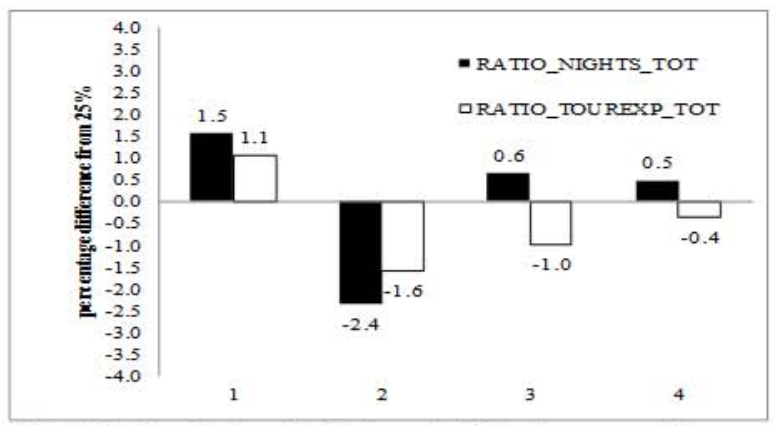

Chart 2b: Quarterly ratios between total touris $m$ expenditures and total touris m nights (2007-2011)

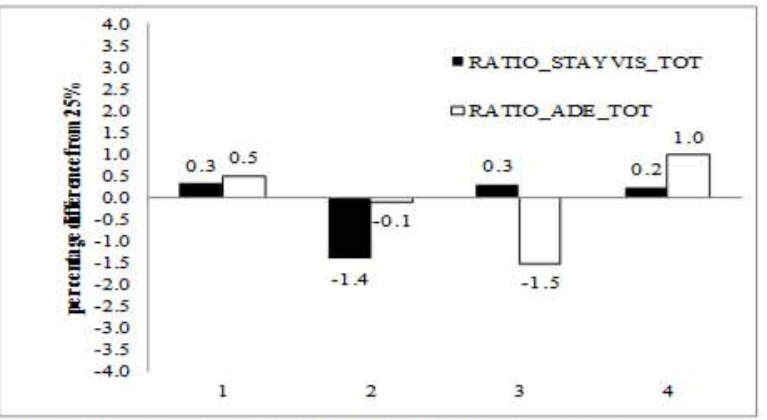

Chart 3b: Quarterly ratios between total average daily expenditure and total stay-over touris m (2007-2011)

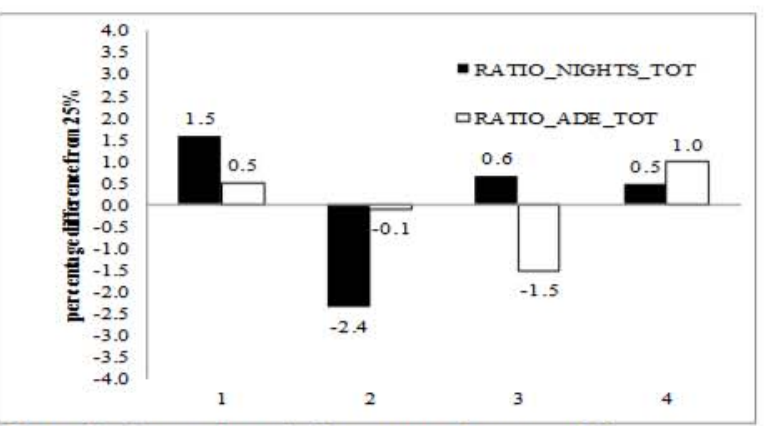

Chart $4 \mathrm{~b}$ : Quarterly ratios between total average daily expenditure and total touris m nights (2007-2011) 
Economic time series often exhibit substantial seasonality, bringing with it the possibility that there may be unit roots at other frequencies than the zero frequency in the spectrum (Hylleberg et al., 1990). Therefore, the time series properties of the data need to be determined in order to make an accurate inference about the seasonal movements in the data (Koc \& Altinay, 2007). The imposition of one kind of seasonality when another one is present can lead to serious biases or loss of information, making it therefore important to establish the kind of seasonality that is present in the series (Beaulieu \& Miron, 1993). Seasonal unit root tests are much more complicated than the simple unit root tests, because they tend to have different unit roots, for example, quarterly, semi-annual and annual basis (Song et al., 2009). Hylleberg et al. (1990) developed a test to determine whether time series contain unit roots at other frequencies than the conventional long-term position. Following Dritsakis (2008), we apply the following HEGY test:

$Y_{4 t}=\pi_{1} Y_{1 t-1}+\pi_{2} Y_{2 t-1}+\pi_{3} Y_{3 t-1}+\pi_{4} Y_{4 t-1}+u_{t}$

Where

$$
\begin{aligned}
Y_{4 t}= & \left(1-L^{4}\right) Y_{t}=Y_{t}-Y_{t-4} \\
Y_{1 t-1}= & \left(1+L+L^{2}+L^{3}\right) Y_{t-1}=Y_{t-1}+Y_{t-2}+Y_{t-3}+Y_{t-4} \\
Y_{2 t-1}= & -\left(1-L+L^{2}-L^{2}\right) Y_{t-1}=-(1-L)\left(1+L^{2}\right) Y_{t-1}=-Y_{t-1}+Y_{t-2}-Y_{t-3}+Y_{t-4} \\
Y_{3 t-1}= & -\left(1-L^{2}\right) Y_{t-2}=-(1-L)(1+L) Y_{t-2}=-Y_{t-2}+Y_{t-4} \\
Y_{4 t-1}= & -\left(1-L^{2}\right) Y_{t-1}=-Y_{t-1}+Y_{t-3} \\
u \quad= & \text { normally and independently distributed error term with zero mean and constant } \\
& \quad \text { variance. } \\
\mathrm{L} \quad= & \text { Backward shift operator }
\end{aligned}
$$

The above equation can be estimated by the ordinary least squares method involving an intercept, a time trend and three seasonal dummies. There are three hypotheses that will be tested here:

1. $H_{0}: \pi_{1}=0, H_{1}: \pi_{1}<0 \rightarrow$ t-test

2. $H_{0}: \pi_{2}=0, H_{1}: \pi_{2}<0 \rightarrow$ t-test

3. $H_{0}: \pi_{3}=0, H_{1}: \pi_{3} \neq 0$ and $\pi_{4} \neq 0 \rightarrow$ F-test 
If the first hypothesis is not rejected $\left(\pi_{1}=0\right)$, then there is a unit root at the zero frequency (or a non-seasonal unit root in the time series). If the second hypothesis is not rejected, then there is a seasonal unit root at the semi-annual frequency. If the third hypothesis is not rejected, there is a unit root at the annual frequency.

Time series usually consist of four components (Trend, Cycle, Seasonal factor and Irregular factor), and can be either multiplicative or additive (Bails \& Peppers, 1993). The multiplicative model is a multiplication of these four components:

$\mathrm{S}=\mathrm{T} \times \mathrm{C} \times \mathrm{S} \times \mathrm{I}$

where:

$$
\begin{array}{ll}
\mathrm{S} & =\text { Series; } \\
\mathrm{T} & =\text { Trend; } \\
\mathrm{C} & =\text { Cycle; } \\
\mathrm{S} & =\text { Seasonal factor; } \\
\mathrm{I} & =\text { Irregular factor. }
\end{array}
$$

In the additive model, the relation between these components is as follows:

$$
\mathrm{S}=\mathrm{T}+\mathrm{C}+\mathrm{S}+\mathrm{I}
$$

The Census X12-ARIMA decomposition method is applied here to each of the series. In economic applications, it is one of the most widely used procedures to decompose a time series (De Cantis \& Ferrante, 2011). This produces a trend-cycle (TC), a seasonal factor (S), and an irregular component (I). Prior to applying the Census X12-ARIMA technique, the data were analyzed for the type of model (additive or multiplicative) they belong to. We apply here the following regression, borrowed from den Butter \& Fase (1988), to assess the model type:

$$
\left|Y-Y_{T}\right|=\alpha+\beta Y_{T}+\varepsilon_{t}
$$

where:

$\mathrm{Y} \quad=$ the original value of the time series; 
$\mathrm{Y}_{\mathrm{T}} \quad=$ the centralized moving average of $\mathrm{Y}$ over a period of a year;

$\alpha, \beta=$ coefficients;

$\varepsilon \quad=$ error term.

If $\mathrm{Y}$ and $\mathrm{Y}_{\mathrm{T}}$ are uncorrelated, meaning that the coefficient $\beta$ is not significantly different from zero, the model type is additive. If $\beta$ is significantly different from zero, the model is multiplicative.

Simultaneously, when applying the Census X12-ARIMA methodology, we test the variables for the presence of seasonality using the following tests included in this decomposition approach: (1) a test for the presence of seasonality assuming stability (an F-test assessing the presence of seasonality at the $0.1 \%$ level); (2) a nonparametric test for the presence of seasonality assuming stability (a Kruskal-Wallis test assessing seasonality at the 1\% level); (3) a moving seasonality test (an F-test assessing moving seasonality at the 5\% level); (4) the ratio between moving seasonality and stable seasonality (according to the U.S. Bureau of Census (2010), this ratio should be less than 1). The two last tests provide information about the degree of variance of the seasonal factor from year to year (Bloem et al., 2001). These four tests will allow us to decide whether seasonality has a key role in the analysis of the monetary and non-monetary variables.

The next analyses are done per quarter to provide a better understanding of seasonality within this timeframe. The seasonal factors of both monetary and non-monetary indicators were first standardized in order to make an adequate comparison with each other. Three types of analyses will be conducted on the standardized data. The first evaluation involves the comparison of the seasonal patterns of the monetary against the non-monetary indicators. The aim here is to assess how much the monetary indicators move in concert with the non-monetary ones. The analysis of the differences in pattern between the standardized monetary and non-monetary indicators is done by calculating the Pearson's correlation statistics, which measures the strength of the association between combinations of monetary and non-monetary indicators.

The second analysis compares the amplitudes of the seasonal patterns of both types of indicators (whereby amplitude is defined here as the difference between the points on the seasonal patterns and zero). The amplitude differences are determined by first calculating the relative differences between the standardized seasonal patterns of both monetary and nonmonetary indicators of tourism demand, using the following formula: 
$A D_{t}=\frac{\left|S M_{t}-S N M_{t}\right|}{\left|S M_{t}\right|} \times 100 \%$

where:
$\mathrm{AD} \quad=$ Amplitude Difference;
$\mathrm{SM}=$ Seasonal pattern of monetary indicators of tourism development;
SNM = Seasonal pattern of non-monetary indicators of tourism development;
$\mathrm{t} \quad=$ Time.

Basically, the $\mathrm{AD}$ determines the absolute difference between the monetary and non-monetary seasonal pattern in percent of the monetary seasonal pattern of tourism development. For instance, if $\mathrm{SM}_{\mathrm{t}}=0.05$ and $\mathrm{SNM}_{\mathrm{t}}=0.07$, the $\mathrm{ADt}=40 \%$ of the $\mathrm{SM}_{\mathrm{t}}$. We calculate the median value of the amplitude differences per quarter in order to get a one-dimensional overview of the results. The median is used here as the preferred measure of central tendency, because it is less subject to large fluctuations than the mean. Additionally, we calculate the median variance statistics for each quarter to determine which seasonal factor (monetary or non-monetary) has the largest amplitude. This is important when discussing strategies to synchronize seasonality in both monetary and non-monetary tourism indicators.

The third analysis encompasses determining the timing difference of occurrence of the seasonal patterns of the monetary versus the non-monetary indicators. The aim here is to measure whether the seasonal patterns of the monetary indicators have a lag, lead or coincident relation with those of the non-monetary indicators. To determine the timing difference between the seasonal patterns of monetary indicators and non-monetary indicators, the seasonal factors for each of the variables are first transformed using a ranking procedure to distinguish between the highest (value $=1$ ) and lowest (value $=4$ ) positions during a year. In formula:

$$
\begin{aligned}
Y_{t, r}=1 & \text { if } Y_{t}>\left(Y_{t+1}, Y_{t+2}, Y_{t+3}\right) ; \\
Y_{t, r}=2 & \text { if } Y_{t+1}>Y_{t}>\left(Y_{t+2}, Y_{t+3}\right) \\
& \text { or } Y_{t+2}>Y_{t}>\left(Y_{t+1}, Y_{t+3}\right) \\
& \text { or } Y_{t+3}>Y_{t}>\left(Y_{t+1}, Y_{t+2}\right)
\end{aligned}
$$




$$
\begin{aligned}
Y_{t, r}=3 & \text { if }\left(Y_{t+2}, Y_{t+3}\right)>Y_{t}>Y_{t+1} \\
& \text { or }\left(Y_{t+3}, Y_{t+1}\right)>Y_{t}>Y_{t+2} \\
& \text { or }\left(Y_{t+1}, Y_{t+2}\right)>Y_{t}>Y_{t+3} \\
Y_{t, r}=4 & \text { if } Y_{t}<\left(Y_{t+1}, Y_{t+2}, Y_{t+3}\right)
\end{aligned}
$$

where $r$ stands for ranked value. Subsequently, we determine the level of lag, lead or coincidence between the monetary and non-monetary seasonal factors, based on their ranking difference over time. For example, if $Y_{t}$ is ranked 4th and $X_{t+3}$ is also ranked at the same number, then $Y_{t}$ is leading $X_{t+3}$ by 3 quarters. Similarly, if $Y_{t+3}$ is ranked $2^{\text {nd }}$ and $X_{t}$ is ranked $2^{\text {nd }}$, we can conclude that $Y_{t+3}$ is lagging on $X_{t}$ by 3 quarters. Again, we calculate here one-dimensional median timing differences for each quarter to assist the analysis.

\section{Empirical Results}

All estimates were obtained from Eviews 7.0 and Microsoft Excel 2010. Seasonal unit root test results show the non-rejection of the first hypothesis for the variables LSTAYVIS_USA, LSTAYVIS_VEN, LNIGHTS_TOT, and all monetary variables, implying that these variables have a unit root at the zero frequency, or a non-seasonal unit root (Table 2). However, the second and third hypotheses are rejected in all cases, meaning that there is no seasonal unit root at the semi-annual and annual frequencies. Given that we intend to work with seasonal factors only, and the absence of seasonal unit roots, there is no further transformation to the data necessary. 
Table 2: Seasonal unit root test results

\begin{tabular}{|c|c|c|c|c|}
\hline \multirow[b]{2}{*}{ Variables } & \multicolumn{3}{|c|}{ Null hypothesis } & \multirow[t]{2}{*}{ Integration } \\
\hline & $\pi_{1}=0$ & $\pi_{2}=0$ & $\pi_{3}=0, \pi_{4}=0$ & \\
\hline \multicolumn{5}{|l|}{ Stay-over tourism } \\
\hline$\overline{\text { LSTAYVIS_TOT }}$ & $7.1383 *$ & $-6.91 \mathrm{E}+13 *$ & $8.67 \mathrm{E}+27 *$ & $\mathrm{I}(0,0,0)$ \\
\hline LSTAYVIS_USA & -0.5482 & $-3.6318 *$ & $134.3726 *$ & $\mathrm{I}(1,0,0)$ \\
\hline LSTAYVIS_VEN & 1.0052 & $-4.3378 *$ & $79.43426 *$ & $\mathrm{I}(1,0,0)$ \\
\hline LSTAYVIS_OTH & $-7.0430 *$ & $-1.26 \mathrm{E}+15 *$ & $1.07 \mathrm{E}+30 *$ & $\mathrm{I}(0,0,0)$ \\
\hline \multicolumn{5}{|l|}{ Tourismnights } \\
\hline$\overline{\text { LNIGHTS_TOT }}$ & 1.8131 & $-2.08 \mathrm{E}+15 *$ & $9.01 \mathrm{E}+30 *$ & $\mathrm{I}(1,0,0)$ \\
\hline LNIGHTS_USA & $6.5395 *$ & $-5.12 \mathrm{E}+15 *$ & $3.71 \mathrm{E}+31 *$ & $\mathrm{I}(0,0,0)$ \\
\hline LNIGHTS_VEN & $-5.6159 *$ & $-4.43 E+15 *$ & $3.04 \mathrm{E}+31 *$ & $\mathrm{I}(0,0,0)$ \\
\hline LNIGHTS_OTH & $-6.4571 *$ & $-2.59 \mathrm{E}+15 *$ & $1.07 \mathrm{E}+31 *$ & $\mathrm{I}(0,0,0)$ \\
\hline \multicolumn{5}{|c|}{ Total expenditure in A ruba expen diture by place of residence } \\
\hline LTOUREXP_TOT & -0.0381 & $-10.1942 *$ & $71.4643 *$ & $\mathrm{I}(1,0,0)$ \\
\hline LTOUREXP_USA & -0.7091 & $-8.0463 *$ & $40.0476 *$ & $\mathrm{I}(1,0,0)$ \\
\hline LTOUREXP_VEN & -0.4839 & $-8.3012 *$ & $29.4543 *$ & $\mathrm{I}(1,0,0)$ \\
\hline LTOUREXP_OTH & -0.7692 & $-11.0288 *$ & $36.4765 *$ & $\mathrm{I}(1,0,0)$ \\
\hline \multicolumn{5}{|c|}{ Average daily expenditure by place of residence } \\
\hline LADE_TOT & -0.4224 & $-8.3763 *$ & $39.4386 *$ & $\mathrm{I}(1,0,0)$ \\
\hline LADE_USA & -0.1996 & $-8.4933 *$ & $37.5492 *$ & $\mathrm{I}(1,0,0)$ \\
\hline LADE_VEN & 0.0371 & $-12.7093 *$ & $28.9120 *$ & $\mathrm{I}(1,0,0)$ \\
\hline LADE_OTH & -0.0773 & $-12.7680 *$ & $27.7250 *$ & $\mathrm{I}(1,0,0)$ \\
\hline
\end{tabular}

Note: The regression includes an intercept, three seasonal dummies and a time trend. The number of observations is 64 . The critical values are taken from Hylleberg et al. (1990) for 100 observartions at the $5 \%$ level: $t(\pi 1)=-3.53, t(\pi 2)=-2.94, t(\pi 3, \pi 4)=$ 6.60 . $*$ indicates that the $t$-value is larger than the critical value, meaning that there is stationarity.

Prior to applying the seasonal decomposition procedure, we tested the data for the type of model (additive or multiplicative) they belong to. According to the results shown in Table 3, most of the variables were of the additive form. This in contrasts with Baron (1975) who argued that most tourism-related time series could be best modeled using the multiplicative approach. 


\begin{tabular}{|c|c|c|}
\hline Variable type & Regression result of $\beta$ & Model type \\
\hline \multicolumn{3}{|l|}{ Stay-over tourism } \\
\hline$\overline{\text { LSTAYVIS_TOT }}$ & -0.0290 & additive \\
\hline LSTAYVIS_USA & $-0.1001 * *$ & multiplcative \\
\hline LSTAYVIS_VEN & 0.0095 & additive \\
\hline LSTAYVIS_OTH & 0.0507 & additive \\
\hline \multicolumn{3}{|l|}{ Tourism nights } \\
\hline$\overline{\text { LNIGHTS_TOT }}$ & -0.0157 & additive \\
\hline LNIGHTS_USA & $-0.1590 *$ & multiplicative \\
\hline LNIGHTS_VEN & $-0.0751 * * *$ & multiplicative \\
\hline LNIGHTS_OTH & $0.0890 * *$ & multiplicative \\
\hline \multicolumn{3}{|c|}{ Total expenditure in Aruba expenditure by place of residence } \\
\hline LTOUREXP_TOT & 0.0258 & additive \\
\hline LTOUREXP_USA & -0.0840 & additive \\
\hline LTOUREXP_VEN & -0.0014 & additive \\
\hline LTOUREXP_OTH & 0.0735 & additive \\
\hline \multicolumn{3}{|c|}{ Average daily expenditure by place of residence } \\
\hline LADE_TOT & 0.0275 & additive \\
\hline LADE_USA & $0.0880 * * *$ & multiplicative \\
\hline LADE_VEN & 0.0570 & additive \\
\hline LADE_OTH & $-0.6502 *$ & multiplicative \\
\hline
\end{tabular}

Note: The symbols * $* *$, and **** in dicate, respectively, $1 \%, 5 \%$ and $10 \%$ significance levels.

With these results, we proceeded to apply the Census X12-ARIMA technique, with the seasonality test results incorporated in Table 4. The F-test for stable seasonality showed significant results in almost all cases, except for LNIGHTS_USA and LADE_OTH. The seasonal factors of these two variables appear to be unstable. The Kruskal-Wallis test shows no evidence of seasonality under the assumption of stability for LADE_OTH, while the F-test for moving seasonality shows little evidence of this event, with the exception of LSTAYVIS_OTH, LTOUREXP_OTH, LADE_TOT and LADE_OTH. The last test, the ratio between moving seasonality and stable seasonality is larger than 1 for LNIGHTS_USA and LADE_OTH. Based on the above-detailed results, we decided to drop the variables LNIGHTS_USA and LADE_OTH from the further analysis in this study. This means that pattern, amplitude, and timing comparisons of seasonal factors between tourism expenditures US market and tourism nights US market, tourism expenditures other markets and tourism nights other markets, average daily expenditures US market and tourism nights US market, average daily expenditures other markets and stay-over other markets, and average daily expenditures other markets and tourism 
nights other markets are not possible in this study, which is considered a delimitation for the ensuing analysis.

\begin{tabular}{|c|c|c|c|c|c|c|c|}
\hline \multirow[b]{2}{*}{ Series } & \multicolumn{2}{|c|}{ Stable seasonality } & \multicolumn{2}{|c|}{$\underline{\text { Kruskal-Wallis test }}$} & \multicolumn{2}{|c|}{ Moving seas onality } & \multirow{2}{*}{$\begin{array}{r}\text { Ratio of moving } \\
\text { seasonality to } \\
\text { stable seasonality }\end{array}$} \\
\hline & F-test & $\begin{array}{l}(0.1 \% \\
\text { level }) \\
\end{array}$ & $\chi^{2}$ & $\begin{array}{r}\text { lue }(1 \% \\
\text { level) } \\
\end{array}$ & F-test & $\begin{array}{r}\mathrm{p} \text {-value }(5 \% \\
\text { level) } \\
\end{array}$ & \\
\hline \multicolumn{8}{|l|}{ Stav-over tourism } \\
\hline LSTAYVIS_TOT & 29.265 & $0.0000 *$ & 41.704 & $0.0000 *$ & 0.743 & 0.7290 & 0.3970 \\
\hline LSTAYVIS_USA & 82.268 & $0.0000 *$ & 54.099 & $0.0000 *$ & 0.916 & 0.5533 & 0.2430 \\
\hline LSTAYVIS_VEN & 141.001 & $0.0000 *$ & 54.366 & $0.0000 *$ & 0.242 & 0.9978 & 0.1660 \\
\hline LSTAYVIS_OTH & 108.067 & $0.0000 *$ & 42.328 & $0.0000 *$ & 1.903 & $0.0489 *$ & 0.2420 \\
\hline \multicolumn{8}{|l|}{ Tourismnights } \\
\hline LNIGHTS_TOT & 149.060 & $0.0000 *$ & 54.923 & $0.0000 *$ & 1.08 & 0.4005 & 0.1850 \\
\hline LNGHTS_USA & 2.935 & 0.0405 & 26.649 & $0.0000 *$ & 1.109 & 0.3764 & 1.3260 \\
\hline LNIGHTS_VEN & 51.484 & $0.0000 *$ & 46.238 & $0.0000 *$ & 1.598 & 0.1127 & 0.3380 \\
\hline LNIGTS_OTH & 8.826 & $0.0001 *$ & 28.353 & $0.0000 *$ & 0.726 & 0.7461 & 0.7210 \\
\hline \multicolumn{8}{|c|}{ Total expenditure in A ruba expenditure by place of residence } \\
\hline LTOUREXP_TOT & 49.020 & $0.0000 *$ & 44.086 & $0.0000 *$ & 1.997 & $0.0375 *$ & 0.3640 \\
\hline LTOUREXP_USA & 90.800 & $0.0000 *$ & 48.897 & $0.0000 *$ & 1.827 & 0.0532 & 0.2640 \\
\hline LTOUREXP_VEN & 20.834 & $0.0000 *$ & 36.09 & $0.0000 *$ & 0.803 & 0.6683 & 0.4200 \\
\hline LTOUREXP_OTH & 9.808 & $0.0000 *$ & 26.238 & $0.0000 *$ & 0.679 & 0.7904 & 0.6790 \\
\hline \multicolumn{8}{|c|}{ A verage daily expenditure by place of residence } \\
\hline LADE_TOT & 17.711 & $0.0000 *$ & 29.235 & $0.0000 *$ & 2.209 & $0.0207 *$ & 0.6200 \\
\hline LADE_USA & 27.564 & $0.0000 *$ & 38.176 & $0.0000 *$ & 1.721 & 0.0807 & 0.4700 \\
\hline LADE_VEN & 9.696 & $0.0000 *$ & 20.1870 & $0.0002 *$ & 1.6230 & 0.1056 & 0.7820 \\
\hline LADE_OTH & 2.510 & 0.0672 & 8.4310 & 0.0379 & 1.9900 & $0.0383 *$ & 1.6070 \\
\hline
\end{tabular}

Note: * indicates significance at the level of testing. The ratio o fmoving seasonality to stable seasonality should be less than 1 to con firm the presence of seasonality (McDonald-Johns on et al., 2010).

Charts $5 \mathrm{a}$ to $8 \mathrm{~d}$ show the seasonal factors for total stay-over tourism, tourism nights, tourism expenditure and average daily rates. Visual inspection shows changing seasonal patterns over time, whereby amplitudes seem to become smaller in most of the cases. For example, in the case of the seasonal factor of stay-over tourism from Venezuela, amplitude differences show a contracting movement, particularly as of 2004/2005. The seasonal factors in these charts confirm the position of Salish \& Rodrigues (2011) that seasonality is not necessarily fixed over time. This is, according to (Franses, 1996), because certain seasonal fluctuations may be triggered by the behavior of economic agents, which may not be constant over time. The ensuing statistical analysis will provide more clues about the patterns, amplitude and timing differences between the monetary and non-monetary seasonal factors. 

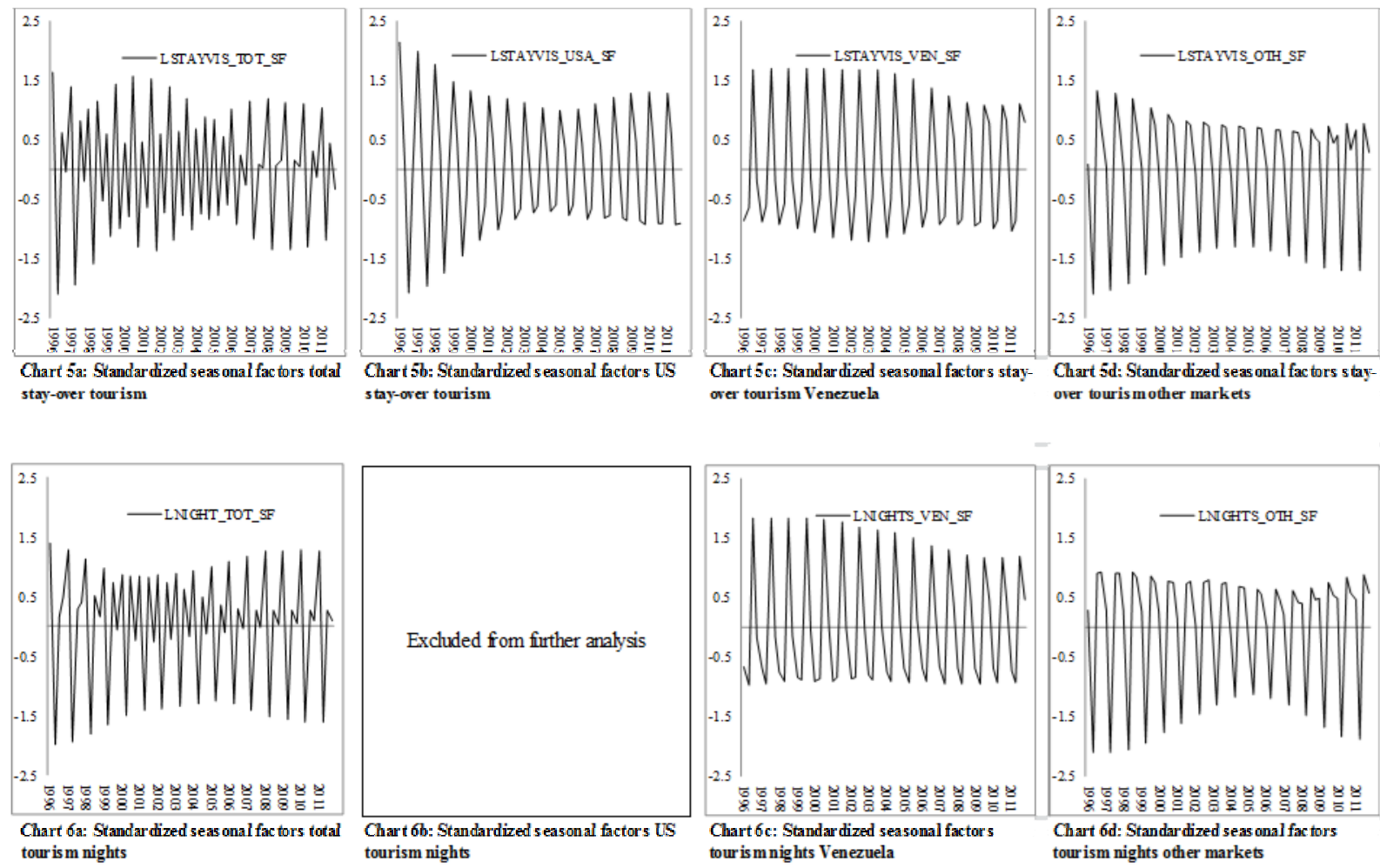

Chart $5 \mathrm{c}$ : Standardized seasonal factors stayover tourism Venezuela over tourismother markets
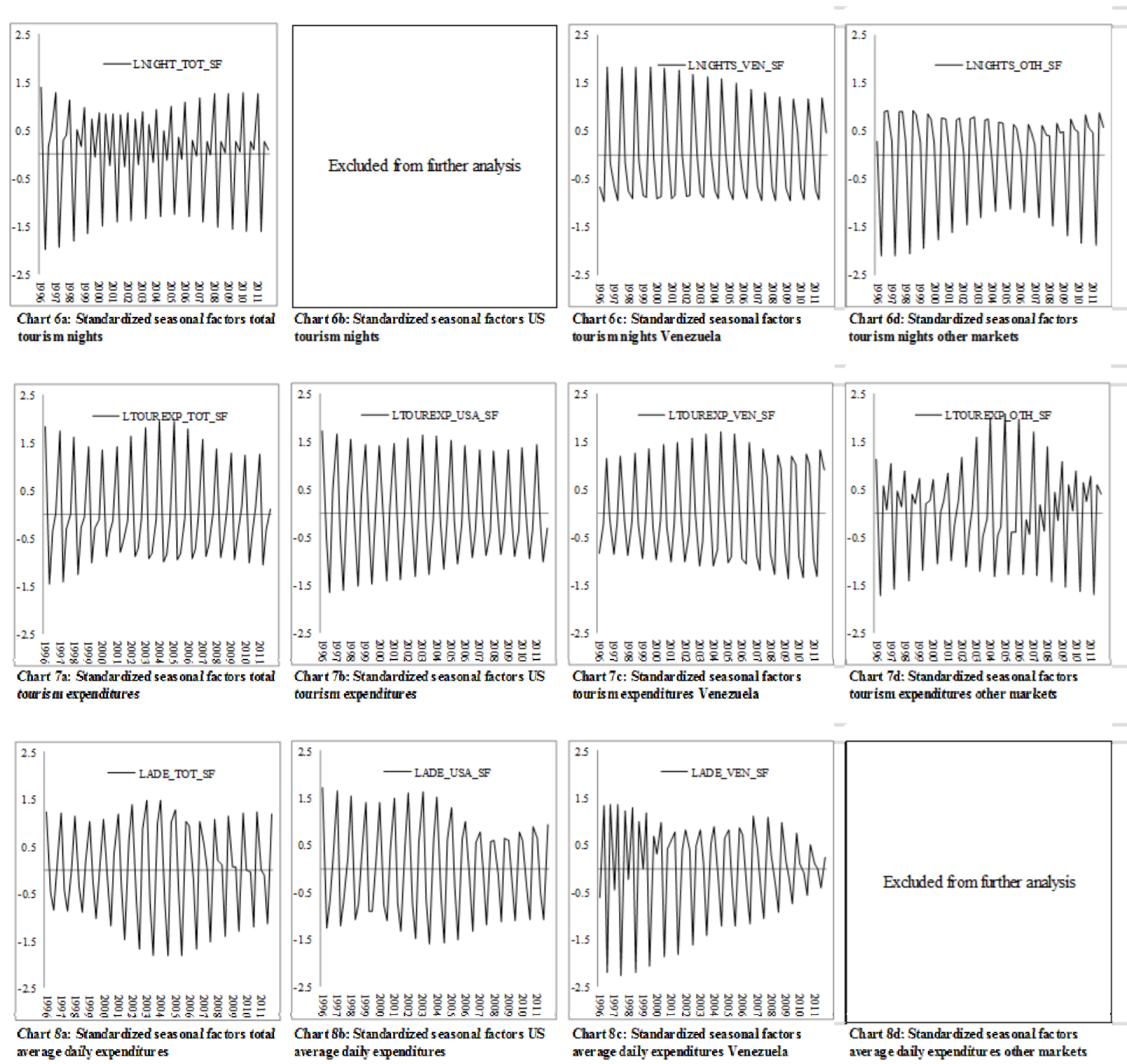

tour is mnights Venezuela

tour ism nights other markets
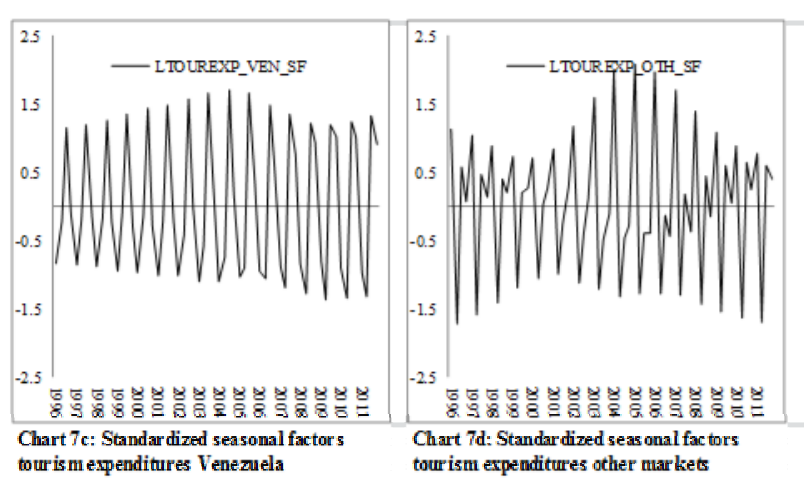

aver age daily expenditures

average daily expenditures

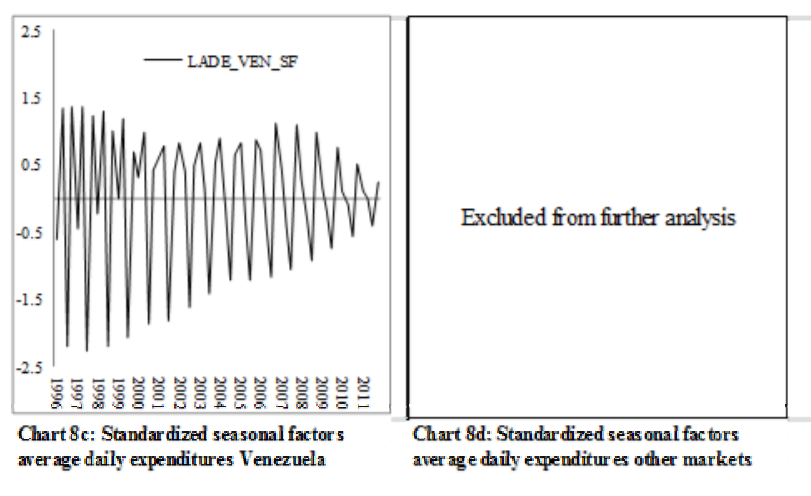

For the correlation analysis, we transformed the data so that we now have all first, second, third and fourth quarter data separated from each other. The reason for this form of analysis is because 
we want to test whether the correlation varies per quarter, as suggested by the initial analysis in Charts 1-4. Applying a correlation analysis on a normal time series would produce information on the level of association for all quarters together, but could hide details about lack of seasonal association during a specific quarter. The latter could prove important when considering synchronization strategies and anti-seasonal policies. Subsequently, we conducted the Pearson's correlation analysis to determine the level of association of combinations of both seasonal factors of monetary and non-monetary indicators. The results are presented in Table 5, for both the whole period (1996-2011) and the sub period (2007-2011). The significant correlation cases are indicated with line borders). The table shows a number of interesting features. Firstly, the level of association is not the same each quarter (in line with the initial analysis in Charts 1-4), indicating variations in the strength of the linear relation between the seasonal monetary and non-monetary variables. For example, while during the first quarter, the seasonal factor of total tourism expenditure shows no significant association with both factors of stay-over tourism and tourism nights for the period 1996-2001, the fourth quarter shows significant relations between both combinations. Similarly, while during the first quarter of the sub period, the Venezuelan market showed significant association (both for stay-over and tourist nights) with the seasonal factor of average daily expenditure by this market, the second, third, and fourth quarters show no significant correlations. Secondly, there are several cases where the associations are significant, but negative, indicating that the direction of one variable is opposite to the other. For example, during the second quarter, the correlation between the seasonal factors of tourism expenditure and stay-over tourism of the US market was negative 0.9668 , indicating that when the seasonal factor of one indicator was moving upwards, the other was almost completely going the opposite direction. Thirdly, the number of significant correlations in the total is larger when the monetary seasonal factor is total tourism expenditure. The relatively low numbers of significant correlations with total average daily expenditure as the monetary seasonal variable is likely to be the result of significant negative correlations in some markets that are cancelling out the significant positive correlations in other markets. These findings provide further clues that a differentiating anti-seasonal approach per quarter may be necessary to tackle these distinguishing outcomes. 
Table 5: Pearson's correlation coefficients of seasonal factors

\begin{tabular}{lllllll} 
Series & LTOUREXP TOT & LTOUREXP USA & LTOUREXP VEN & LTOUREXP OTH & LADE TOT & LADE USA \\
\hline
\end{tabular}

First quarter

$\underline{1996-2011}$

LSTAYVIS TOT

LSTAYVIS_USA

LSTAYVIS_VEN

LSTAYVIS OTH

LNIGHTS TOT

LNIGHTS_VEN

0.0736

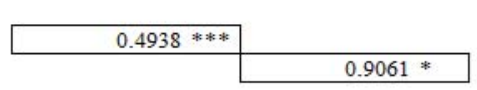

$-0.3811$

$-0.2096$

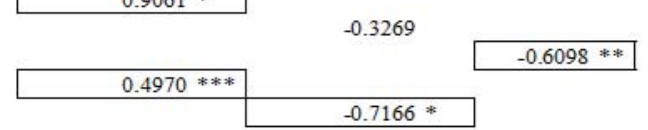

0.3962

LNIGHTS_OTH

2007-2011

LSTAYVIS_TOT

LSTAYVIS_USA

LSTA YVIS_VEN

LSTAYVIS_OTH

LNIGHTS TOT

LNIGHTS_VEN

LNIGHTS_OTH

0.4529

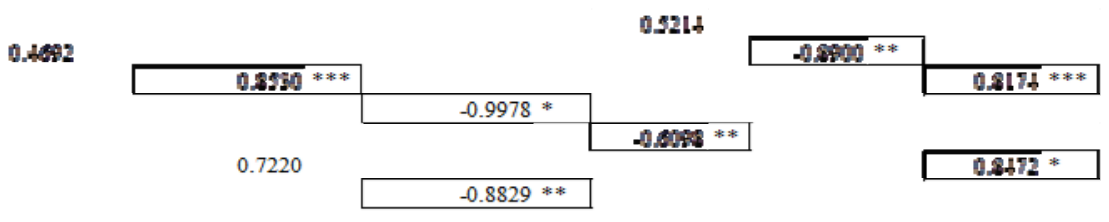

Second quarter

1996-2011

LSTA YVIS TOT

LSTAYVIS USA

LSTAYVIS_VEN

LSTA YVIS_OTH

LNIGHTS TOT

LNIGHTS_VEN

LNIGHTS_OTH
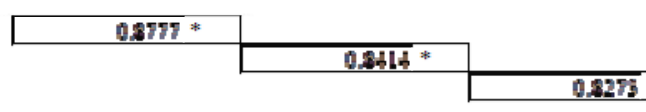

$6872 *$

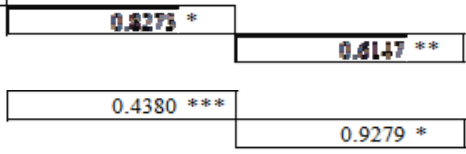

$-0.2309$

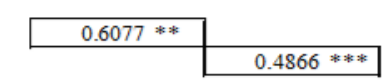

0.2120

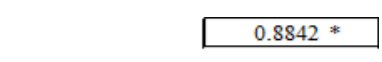

2007-2011

LSTAYVIS_TOT

LSTA YVIS_USA

LSTAYVIS_VEN

LSTA YVIS_OTH

LNIGHTS_TOT

LNIGHTS VEN

LNIGHTS_OTH

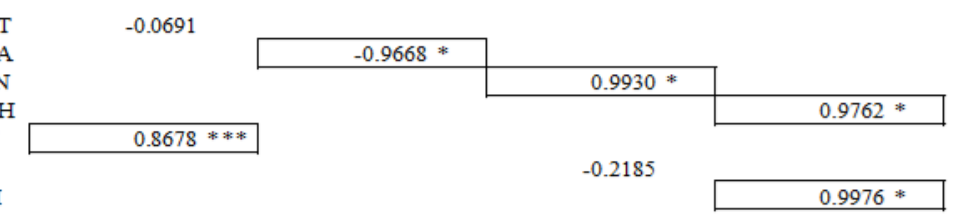

$-0.5661$

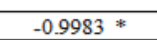

0.4721

$-0.6809$

Third quarter

1996-2011

LSTAYVIS_TOT

LSTAYVIS USA

LSTAYVIS_VEN

LSTAYVIS_OTH

LNIGHTS TOT

LNIGHTS_VEN

LNIGHTS_OTH

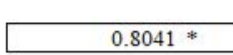

$-0.5754 * *$

0.3594

$-0.1098$

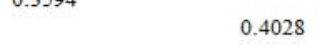

0.4028

0.0965

2007-2011

LSTAYVIS_TOT

LSTAYVIS_USA

LSTAYVIS_VEN

LSTAYVIS_OTH

LNIGHTS_TOT

LNIGHTS_VEN

LNIGHTS_OTH

0.1484

$0.6052 * *$

$-0.4042$

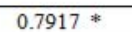

$-0.2958$

Fourth quarter

1996-2011

LSTAYVIS_TOT

LSTAYVIS_USA

LSTAYVIS_VEN

LSTAYVIS_OTH

LNIGHTS_- TOT

LNIGHTS_VEN

LNIGHTS_OTH

$0.8491 * * *$

$0.9596 *$

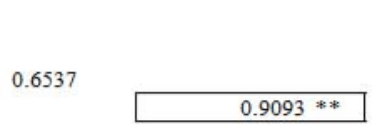

$-0.4563$

0.7244

$0.8425 * * *$

0.5940

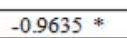

$-0.3665$

0.6924

2007-2011

LSTAYVIS_TOT

LSTAYVIS_USA

LSTA YVIS_VEN

LSTAYVIS_OTH

LNIGHTS_TOT

LNIGHTS_VEN

LNIGHTS_OTH

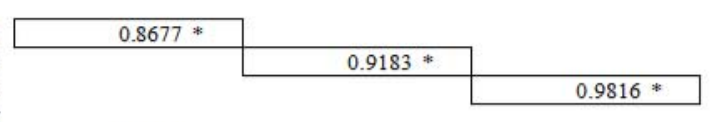

0.2456

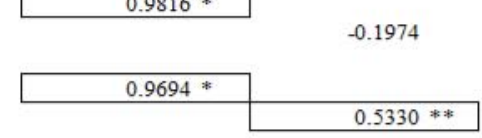

$-0.4042$

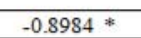

$0.5341 * *$

(1)

Note: $* * *$ and $* * *$ indicate, respectively, $1 \%, 5 \%$ and $10 \%$ significance (two-tailed). 
The notable differences in significant association between the monetary and non-monetary seasonal factors may be further explained by analyzing these factors in terms of their amplitude and timing differences. Table 6 provides the median results of these calculations, per timeframe (1996-2011 and 2007-2011), per quarter, and per market. Median amplitude differences were calculated for the total and all markets selected in the study. Additionally, the median variances were calculated to determine which seasonal factor, monetary or non-monetary was the largest in terms of their amplitude. The results first show significant differences in median amplitudes between the monetary and non-monetary seasonal factors per quarter, but also per period of analysis. For the period 1996-2011, the largest median amplitude differences are found in the third and fourth quarters, while the first quarter has the smallest amplitude differences. When analyzing the sub period, the smallest amplitude differences were found in the third and fourth quarters, while the first and second quarters had the largest amplitude differences. The latter is because there are some significantly large amplitude differences, particularly when the monetary seasonal factor is the average daily expenditure. The calculated median variances show the monetary seasonal factor is larger than the non-monetary seasonal factor in the first, second and fourth quarters, for both period of analysis, meaning no change in the structure of the relation between both monetary and non-monetary seasonal factors. The non-monetary seasonal factor is larger than the monetary seasonal factor in the third quarter, again for both periods.

The results of the timing differences between the seasonal factors of both monetary and nonmonetary indicators are also incorporated in Table 6. While for the period 1996-2011, the median timing differences for both seasonal factors of monetary and non-monetary indicators seem to coincide in the first and second quarters, the seasonal patterns of the monetary indicators generally lead those of the non-monetary indicators by 1 quarter in the third quarter, while lagging by 2 quarters in the fourth quarter. For the sub period, the monetary seasonal indicators lead those of the non-monetary indicators by 1 quarter in the first and third quarters. The timing in the second quarter is the same as in the whole period (coincident). The timing difference between the whole period and sub period in the fourth quarter remains the same (lag of 2 quarters). 


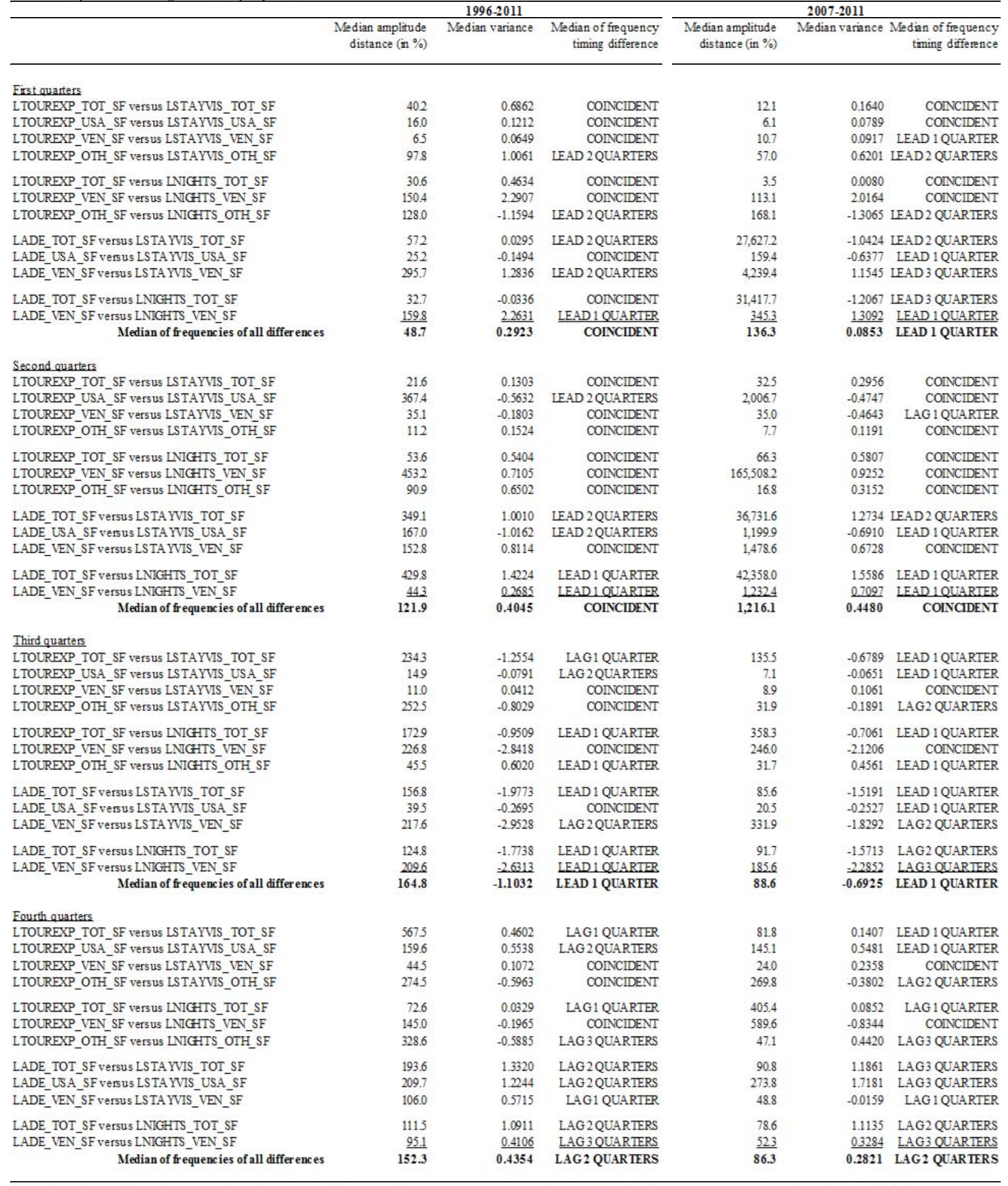

Note: Calculations are based on standardized values. The median variance is caclulated to determine which seas onal pattern (monetary or non-monetary) is the larg est. A "." signs indicates in this case that the value of the seasonal pattern of the non-monetary variable is larg er than the monetary variable.

Having identified the differences between seasonality of monetary and non-monetary tourism indicators, the final step is to delineate a cluster of possible strategies to mitigate the gap between 
the seasonal factors of monetary and non-monetary indicators, from the perspective of the sub period (2007-2011). This period is selected here under the assumption that this period provides a better indication of current seasonal developments, given its more recent occurrence, and is then more suitable for policy purposes. The approach here is to consider each quarter of the sub period separately, while involving all influential markets in the strategy formulation. The proposed strategies are based in part on the literature on anti-seasonal policies (e.g., KoenigLewis \& Bischoff, 2005; Lee et al., 2008; Cannas, 2012). However, for the sake of better understanding, these proposed measures should not be considered as anti-seasonal policy recommendations, but as strategies aimed at reducing the differences in seasonal factors between both monetary and non-monetary indicators. The results are included in Table 7. The proposed strategies depend on the outcome of the specific measurement dimensions (correlation, amplitude or timing), and also on the markets possibly affecting the overall outcome in these measures. The first and second quarters have some incidences where no specific actions were required. For example, no specific actions were deemed necessary in the case of both amplitude and timing differences for the combination of the seasonal factors of total tourism expenditure and total stay-over tourism in the second quarter. Most of the strategies were proposed in the third and fourth quarters, indicative of the largest number of disruptions in all three applied measures occuring in these two periods. 


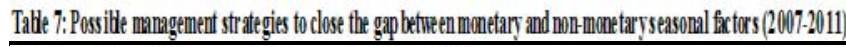

\begin{tabular}{|c|c|c|c|c|c|}
\hline $\begin{array}{l}\text { Peind } \\
\text { of } \\
\text { aralysis }\end{array}$ & $\begin{array}{l}\text { Main variables' seasonalfactors } \\
\text { involved }\end{array}$ & $\begin{array}{l}\text { Type of } \\
\text { amalysis }\end{array}$ & Findings & Most probable causing varibbles) & Possiblestrategy \\
\hline \multirow[t]{12}{*}{$\begin{array}{l}\text { First } \\
\text { quanter }\end{array}$} & \multirow[t]{3}{*}{$\begin{array}{l}\text { Total tourismexpenditure versus } \\
\text { total lstay-overat tourism }\end{array}$} & Conelation & Nosignifixant coneltion & 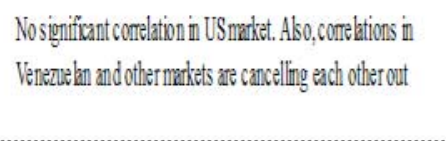 & 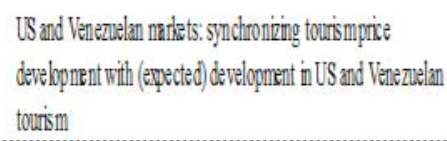 \\
\hline & & $\begin{array}{l}\text { Anplitide } \\
\text { difierences }\end{array}$ & 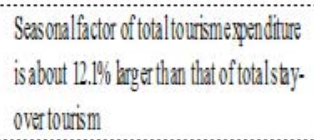 & 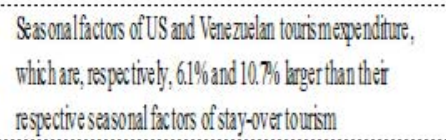 & No specifir a cionnequirad \\
\hline & & $\begin{array}{l}\text { Timing } \\
\text { differences }\end{array}$ & Coincident & Concident US marlat & No specifix x ctionerequired \\
\hline & \multirow[t]{3}{*}{$\begin{array}{l}\text { Total toursmexpenditure vesus } \\
\text { total tourismnigiths }\end{array}$} & Conelation & Significant negative comeltion & Significantregative corretion other mantet & 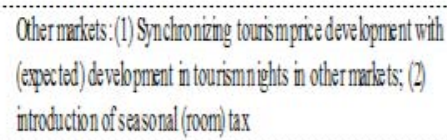 \\
\hline & & $\begin{array}{l}\text { Amplitude } \\
\text { difierences }\end{array}$ & 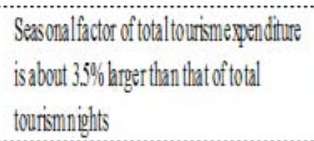 & $\begin{array}{l}\text { Anplitude differences ofter nariets (not incudded in the } \\
\text { analysis) }\end{array}$ & No specifie a cion nequined \\
\hline & & $\begin{array}{l}\text { Timing } \\
\text { differences }\end{array}$ & Coincident & Coincident US mandet & No specific action nequitad \\
\hline & \multirow[t]{3}{*}{$\begin{array}{l}\text { Totalavenage dally expenditure } \\
\text { versus total stay-over toursm }\end{array}$} & Comelation & Nosignificant comedation & 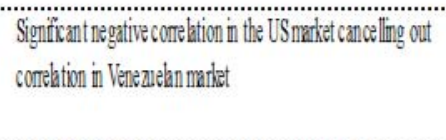 & 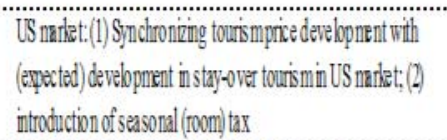 \\
\hline & & $\begin{array}{l}\text { Anpitidude } \\
\text { differences }\end{array}$ & $\begin{array}{l}\text { Sesonal factor of totalaveage daity } \\
\text { eppenditure is about 27,62\% osnaller than } \\
\text { that of total stay-overtoursm }\end{array}$ & 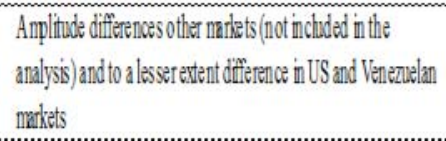 & 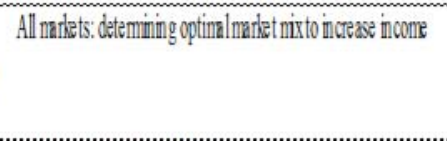 \\
\hline & & $\begin{array}{l}\text { Timing } \\
\text { differences }\end{array}$ & $\begin{array}{l}\text { Seasonal factor total averaged dally } \\
\text { expenditure leads over that of total stay. } \\
\text { overt toursmby } 2 \text { quaters }\end{array}$ & 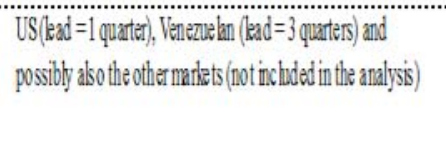 & 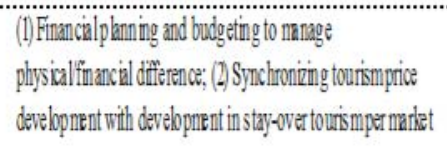 \\
\hline & \multirow[t]{3}{*}{$\begin{array}{l}\text { Totalaverage dealyevenenditure } \\
\text { versis total toursmnights }\end{array}$} & Comelation & Significant negative comedion & Posibly, negative conlation in USando oter markits & 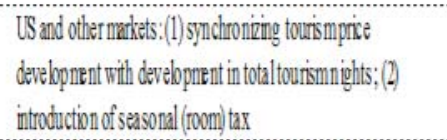 \\
\hline & & $\begin{array}{l}\text { Anpitide } \\
\text { differences }\end{array}$ & $\begin{array}{l}\text { Seasonal factor of totalaveage daly } \\
\text { exenditure is about3 } 31,417 \% \text { snallet than } \\
\text { that of total toursmingights }\end{array}$ & 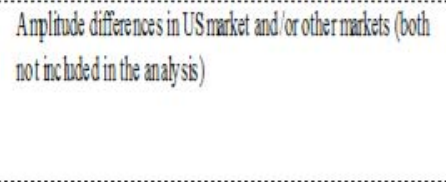 & 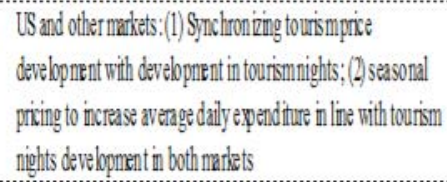 \\
\hline & & $\begin{array}{l}\text { Timing } \\
\text { differences }\end{array}$ & 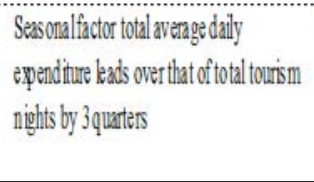 & 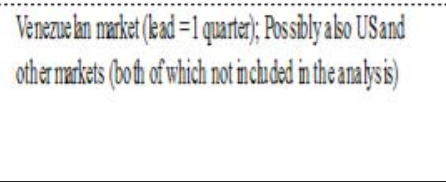 & 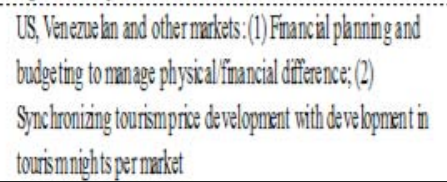 \\
\hline
\end{tabular}


Talle 7: Possille management strategies to close the gap betureen monetary and non-monetary seasonal farctors (2007-2011) (continued)

\begin{tabular}{|c|c|c|c|c|c|}
\hline $\begin{array}{l}\text { Period } \\
\text { of } \\
\text { analysis }\end{array}$ & $\begin{array}{l}\text { Main variables' seasonal factors } \\
\text { involved }\end{array}$ & $\begin{array}{l}\text { Type of } \\
\text { analysis }\end{array}$ & Findings & Most probable causing varibbla $(\mathrm{s})$ & Possible strategy \\
\hline \multirow[t]{3}{*}{$\begin{array}{l}\text { Sevond } \\
\text { quarter }\end{array}$} & \multirow[t]{3}{*}{$\begin{array}{l}\text { Total tourismependiture versus } \\
\text { totalstay-over tourism }\end{array}$} & Comelation & Nosignificant comelation & $\begin{array}{l}\text { Significant ne gative comeation US mantet nny be cancelling } \\
\text { out the results in the o ther narkets }\end{array}$ & 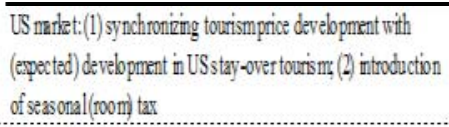 \\
\hline & & $\begin{array}{l}\text { Amplitude } \\
\text { differences }\end{array}$ & $\begin{array}{l}\text { Seasonalfactor of total tourismerpenditure } \\
\text { is about } 32.5 \% \text { brger than that of totalstay- } \\
\text { over tourism }\end{array}$ & Anplitude differences in Venezue bn and other naxkets & No specifix action required \\
\hline & & $\begin{array}{l}\text { Tring } \\
\text { differences }\end{array}$ & Coincident & Coincident US and other markets & No specific action required \\
\hline
\end{tabular}

\begin{tabular}{|c|c|c|c|c|}
\hline \multirow{3}{*}{$\begin{array}{l}\text { Total tourismependiture versus } \\
\text { total tourismnights }\end{array}$} & Comelation & Significant comelation & Signifiant toonelation in other markts & No specifir action required \\
\hline & $\begin{array}{l}\text { Amplitude } \\
\text { differences }\end{array}$ & $\begin{array}{l}\text { Seasona factor of total tourismemenditure } \\
\text { is about } 66.3 \% \text { larger than that of total } \\
\text { tourismnights }\end{array}$ & $\begin{array}{l}\text { Anplitude differences other nantets and possibly US market } \\
\text { (not inchded in the analysis) }\end{array}$ & No specifir action nequired \\
\hline & $\begin{array}{l}\text { Trimg } \\
\text { differences }\end{array}$ & Coincident & $\begin{array}{l}\text { Coincident Venezulan and other markits, and possibly also the } \\
\text { US market (not incuded in the analysis) }\end{array}$ & No specifix action required \\
\hline
\end{tabular}

\begin{tabular}{|c|c|c|c|c|}
\hline \multirow[t]{3}{*}{$\begin{array}{l}\text { Total average daily expenditure } \\
\text { versus total stayy-over tourism }\end{array}$} & Comelation & Nosignificant conelation & $\begin{array}{l}\text { No signifiant conelation in the Venezulan market, and } \\
\text { possibly also in US and other narkits }\end{array}$ & 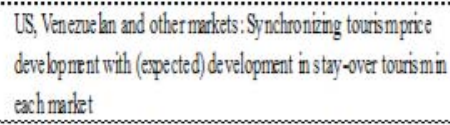 \\
\hline & $\begin{array}{l}\text { Amplitude } \\
\text { differences }\end{array}$ & $\begin{array}{l}\text { Seasonal factor of totalaveage daly } \\
\text { epend thue is about } 36,731 \% \text { brger than } \\
\text { that of total stay-over tourism }\end{array}$ & $\begin{array}{l}\text { Anplitude differences other narlat s (not included in the } \\
\text { analysis), and to sone extent abo the Venezuelan and US } \\
\text { makkets }\end{array}$ & 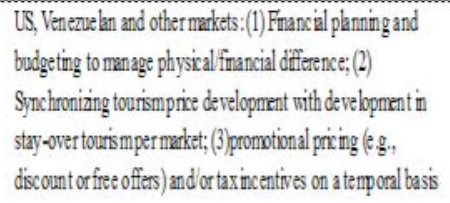 \\
\hline & $\begin{array}{l}\text { Timing } \\
\text { differences }\end{array}$ & $\begin{array}{l}\text { Seasonal factor total average dally } \\
\text { ependiture leads over that of to tal stay. } \\
\text { over tourismby } 2 \text { quarters }\end{array}$ & 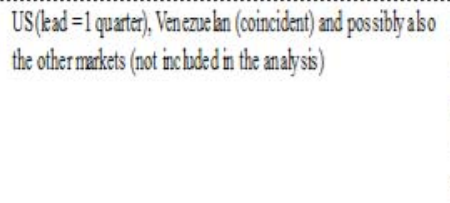 & 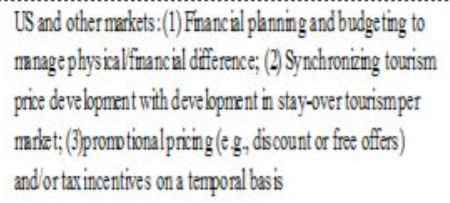 \\
\hline \multirow[t]{3}{*}{$\begin{array}{l}\text { Totalaverage daily expenditure } \\
\text { versus total tourismnights }\end{array}$} & Comelation & Nosignificant come ation & $\begin{array}{l}\text { No significant conelation in Venezulan narlat; Possibly also } \\
\text { the case with the US and other markets (not included in the } \\
\text { analysis) }\end{array}$ & $\begin{array}{l}\text { US, Venezue an and other makets: synconizing tourismprice } \\
\text { developnent with developnent in toursismnights pernarkt }\end{array}$ \\
\hline & $\begin{array}{l}\text { Amplitude } \\
\text { differences }\end{array}$ & $\begin{array}{l}\text { Seasonal factor of totalaveage daily } \\
\text { exenditure is about } 42356 \% \text { smaller than } \\
\text { that of total tourismnights }\end{array}$ & $\begin{array}{l}\text { Anplitude differences in US makket and or other makkts (both } \\
\text { not included in the analysis), and to sont estent abo the } \\
\text { Venezve an makket }\end{array}$ & 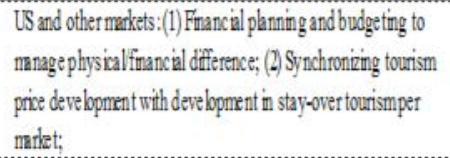 \\
\hline & $\begin{array}{l}\text { Timing } \\
\text { differences }\end{array}$ & $\begin{array}{l}\text { Seasonal factor total average dally } \\
\text { expenditure leads over that of total tourism } \\
\text { nights by lquanter }\end{array}$ & $\begin{array}{l}\text { Venezue lan maket (lead lquarter); Also, pos sible effects by US } \\
\text { and other markits (both not incuded in the analysis) }\end{array}$ & 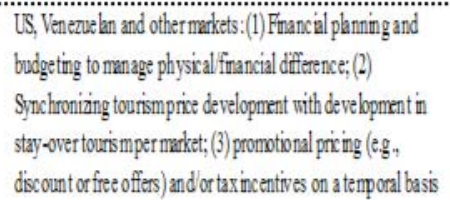 \\
\hline
\end{tabular}


Table 7: Possible management strategies to close the gap between monetary and non-monetary se as an al factors (2007-2011) (continued)

\begin{tabular}{|c|c|c|c|c|c|}
\hline $\begin{array}{l}\text { Period } \\
\text { of } \\
\text { analysis }\end{array}$ & $\begin{array}{l}\text { Main variab les' seasonal factors } \\
\text { involved }\end{array}$ & $\begin{array}{l}\text { Type of } \\
\text { analysis }\end{array}$ & Findings & Most probable causing variable(s) & Recommended strategy \\
\hline \multirow{12}{*}{$\begin{array}{l}\text { Third } \\
\text { quarter }\end{array}$} & \multirow{3}{*}{$\begin{array}{l}\text { Total tounsm eppenditure versus } \\
\text { totalstay-over tourism }\end{array}$} & Comelation & Significant comelation & Sign ifrant come ations in US and other markets & No specific action required \\
\hline & & $\begin{array}{l}\text { Amplitude } \\
\text { differences }\end{array}$ & $\begin{array}{l}\text { Seasonalfactor of totaltourism ependiture } \\
\text { is about } 135.5 \% \text { brger than that of totalstay. } \\
\text { over tourism }\end{array}$ & $\begin{array}{l}\text { Possibly the fact that the median variance for both the US and } \\
\text { other markets are negative, meaning that the ir seasonal factors } \\
\text { of tounism ependiture is generally smaller than those of stay- } \\
\text { over tourism In the case of the Venezuelan market, this is the } \\
\text { other ray around. }\end{array}$ & $\begin{array}{l}\text { US and other markets:(1) Fin ancialplanning and budge ting to } \\
\text { mana ge physicalfinancial difference; (2) Synchronizing tourism } \\
\text { price development with development in stay-over tourism per } \\
\text { marict; (3) promotional pricing (eg, discount of free offers) } \\
\text { and or tax incentives on a temporal basis }\end{array}$ \\
\hline & & $\begin{array}{l}\text { Timing } \\
\text { differences }\end{array}$ & $\begin{array}{l}\text { Seasonalfactor total tourism expenditure } \\
\text { leads over that of total stay-over tourism by } \\
1 \text { quarters }\end{array}$ & US market (lead 1 quarter) & $\begin{array}{l}\text { US market: (1) Financialplanning and budgeting to manage } \\
\text { physicalfinancial difference; (2) Synchronizing tourism price } \\
\text { development with development in stay-over tourism per market; } \\
\text { (3) promotional pricing (eg, discount or free offers) and or tar. } \\
\text { incentives on a temporal basis }\end{array}$ \\
\hline & \multirow[t]{3}{*}{$\begin{array}{l}\text { Totaltourism expenditure versus } \\
\text { total tourism nights }\end{array}$} & Comelation & No significant comelation & $\begin{array}{l}\text { No significant corre ation in Venezue lan maxket possibly } \\
\text { cance ling out the positive correlation in o ther markets. } \\
\text { Possibly, the US market also has no signific ant corre lation (not } \\
\text { included in the analysis) }\end{array}$ & $\begin{array}{l}\text { Venezuelan (and possibly US) markets: synchronizing tourism } \\
\text { price development with deve lopment in tourism nights per } \\
\text { market; }\end{array}$ \\
\hline & & $\begin{array}{l}\text { Amplitude } \\
\text { differences }\end{array}$ & $\begin{array}{l}\text { Seasonalfactor of total tourism eqpenditure } \\
\text { is about } 3583 \% \text { smaller than that of total } \\
\text { tourism nights }\end{array}$ & $\begin{array}{l}\text { Amplitude differences in Venezuelan market, and possibly the } \\
\text { US market as well(not inchded in the analysis) }\end{array}$ & $\begin{array}{l}\text { Venezuelan (and possib ly US) markets: (1) Financialplanning and } \\
\text { bud geting to manage physical francial difference, (2) } \\
\text { Synchronizing to urism price development with development in } \\
\text { tourism nights per market }\end{array}$ \\
\hline & & $\begin{array}{l}\text { Timing } \\
\text { differences }\end{array}$ & $\begin{array}{l}\text { Seasonalfactor total tourism empenditure } \\
\text { leads over that of total tourism nights by } 1 \\
\text { quarters }\end{array}$ & $\begin{array}{l}\text { Oher maikets (bad = } 1 \text { quarter) and poss ibly also the US } \\
\text { market (not inchuded in the analysis) }\end{array}$ & $\begin{array}{l}\text { Other markats:(1) Financialplanning and budgeting to manage } \\
\text { physicalfinancialdifference; (2) Synchronizing tourism price } \\
\text { development with developnent in tourism nights per market, } \\
\text { (3)promo tional pricing ( } \mathrm{g} g \text {, discount or free offers) and or tax } \\
\text { incentives on a temporal basis }\end{array}$ \\
\hline & \multirow[t]{3}{*}{$\begin{array}{l}\text { Totala verage daily expend iture } \\
\text { versus totalstay-over tourism }\end{array}$} & Comelation & No significant correlation & $\begin{array}{l}\text { No significant corre lation in Venezue lan market, and possib ly } \\
\text { also in the other markets (not included in the analysis) } \\
\text { cancelling the significant ne gative corre lation in the US market }\end{array}$ & $\begin{array}{l}\text { US, Venezue a and other markets: (1) Financial planing and } \\
\text { bud geting to manage physicalfinancial difference; (2) } \\
\text { Synchron izing tourism price development with development in } \\
\text { stay-over tourisu per market; (3)promotional pricing (eg. } \\
\text { discount or free offers) and or tar incentives on a temporal basis }\end{array}$ \\
\hline & & $\begin{array}{l}\text { Amplitude } \\
\text { differences }\end{array}$ & $\begin{array}{l}\text { Seasonalfactor of totalaverage daily } \\
\text { ependiture is a bout } 85 . \% \% \text { smaller than that } \\
\text { of total stay-over tourism }\end{array}$ & $\begin{array}{l}\text { Ampitude differences in Venezuelan an possibly other mariets } \\
\text { (not included in the analysis) }\end{array}$ & $\begin{array}{l}\text { Venezuelan and other markets: (1) Frnancial planning and } \\
\text { bud geting to manage physical francial difference; (2) } \\
\text { Synchron ining tourism price deve lopnent with developnent in } \\
\text { tourism nights per market, (3)promotional pricing (e.g, discount } \\
\text { of free offers) and or tar incentives on a temporal basis }\end{array}$ \\
\hline & & $\begin{array}{l}\text { Timing } \\
\text { differencesces }\end{array}$ & $\begin{array}{l}\text { Seasonalfactor to tal average daily } \\
\text { eppenditure leads over that of totalstay. } \\
\text { over tourism by } 1 \text { quarter }\end{array}$ & $\begin{array}{l}\text { US (lead = } 1 \text { quarter), and possibly also the other markets (not } \\
\text { included in the analysis) }\end{array}$ & $\begin{array}{l}\text { US market. (1) Financialplanning and budgeting to manage } \\
\text { physicalfinancial difference; (2) Synchronizing tourism price } \\
\text { de velopment with development in stay-over tourism; } \\
\text { (3)promotional pricing (eg, discount or free offers) and or tax } \\
\text { incentives on a temporal basis }\end{array}$ \\
\hline & \multirow[t]{3}{*}{$\begin{array}{l}\text { Totalaverage daily eppend iture } \\
\text { versus total tourism nights }\end{array}$} & Comelation & No significant conrelation & $\begin{array}{l}\text { No significant corre lation in Venezue an market, possibly also } \\
\text { not in the US and other markets (both not included in the } \\
\text { analysis) }\end{array}$ & $\begin{array}{l}\text { US, Venezue bn and other markets: synchronizing tourism price } \\
\text { development with (empected) vo lune development }\end{array}$ \\
\hline & & $\begin{array}{l}\text { Amplitude } \\
\text { differences }\end{array}$ & $\begin{array}{l}\text { Seasonalfactor of total avera ge daily } \\
\text { exenditure is about } 91 . \% \text { sua aller than that } \\
\text { of total tourism nights }\end{array}$ & $\begin{array}{l}\text { Amplitude dfferences in Veneavelan market, and possibly also } \\
\text { in US and other mariets (both not included in the analysis) }\end{array}$ & $\begin{array}{l}\text { Venezuelan market:(1) Financial planning and budgeting to } \\
\text { manage physicalfinancial difference; (2) Synchronizing tourism } \\
\text { price deve lopment with development in tourisn nights; } \\
\text { (3)promotional pricing (e g, discount on free offers) and or tax } \\
\text { incentives on a temporal basis }\end{array}$ \\
\hline & & $\begin{array}{l}\text { Timing } \\
\text { differences }\end{array}$ & $\begin{array}{l}\text { Seas onalfactor to tal average daily } \\
\text { expenditure lags over that of total tourism } \\
\text { nights by } 2 \text { quarters }\end{array}$ & $\begin{array}{l}\text { Vene zuelan market (lag = } 3 \text { quarters); a lso possible lags in US } \\
\text { and other markets (not included in the analysis) }\end{array}$ & $\begin{array}{l}\text { Venezuelan market: (1) Fin ancialplanning and budgeting to } \\
\text { manage physicalifnancial difference; (2) Synchronizing tourism } \\
\text { price deve lopment with development in tourism nights; } \\
\text { (3)promotionalpricing (eg, discount or free offers) and or tax } \\
\text { incentives on a temporal basis }\end{array}$ \\
\hline
\end{tabular}


Tabe 7: Possibe manngement strategies toclose the gap between monetary and nor-monetary se a sonal factors (2007-2011) (continued)

\begin{tabular}{|c|c|c|c|c|c|}
\hline $\begin{array}{l}\text { Period } \\
\text { of } \\
\text { analysis }\end{array}$ & $\begin{array}{l}\text { Main variables' seasonal factors } \\
\text { involved }\end{array}$ & $\begin{array}{l}\text { Type of } \\
\text { analysis }\end{array}$ & Findings & Most probable causing variable(s) & Recomended strategy \\
\hline \multirow[t]{3}{*}{$\begin{array}{l}\text { Fourth } \\
\text { quarter }\end{array}$} & \multirow[t]{3}{*}{$\begin{array}{l}\text { Total tounismexpenditure versus } \\
\text { totalstay-over tourism }\end{array}$} & Conclation & No significant conelation & 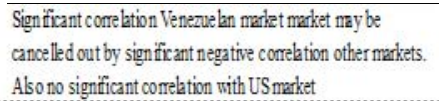 & $\begin{array}{l}\text { US and other mafkets synchroning tourismprice development } \\
\text { with (epocted) stay-vver development in both makkets }\end{array}$ \\
\hline & & $\begin{array}{l}\text { Amplitude } \\
\text { differences }\end{array}$ & $\begin{array}{l}\text { Seasonalfactor of total tourismependiture } \\
\text { is about } 81.8 \% \text { larger than that of total stay- } \\
\text { overt tourism }\end{array}$ & $\begin{array}{l}\text { Combination of anplitude difterences in all three analyzed } \\
\text { marlits }\end{array}$ & 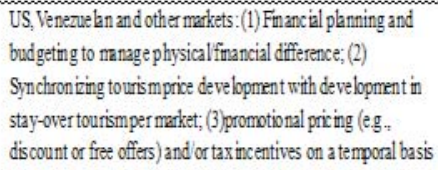 \\
\hline & & $\begin{array}{l}\text { Tring } \\
\text { differences }\end{array}$ & $\begin{array}{l}\text { Seasonalfactort total tourismerpenditure } \\
\text { kads over that of total stay-over tourismby } \\
1 \text { quarter }\end{array}$ & US markt (lead lquarter) & $\begin{array}{l}\text { US makket. (1) Financialplanning and budgeting to manage } \\
\text { phys sical financial differencec; (2) Synchroniang tourismpice } \\
\text { development vith development in stay-over tourism } \\
\text { (3)pronotional pricing (eg, discount of free offers) and or tax } \\
\text { incentives on a temporal basis }\end{array}$ \\
\hline
\end{tabular}

\begin{tabular}{|c|c|c|c|c|}
\hline \multirow[t]{3}{*}{$\begin{array}{l}\text { Total tounismeyenditure versus } \\
\text { total tourismnights }\end{array}$} & Conelation & No significant comelation & $\begin{array}{l}\text { Most probabbly no signifiant comelation in US nights (not } \\
\text { inctuded in the analysis) cancelling out the positive correlations } \\
\text { in Venezule and and other marlets }\end{array}$ & $\begin{array}{l}\text { US makket. Synchronizing tourismprice developments with } \\
\text { (expected) development in tourismnights }\end{array}$ \\
\hline & $\begin{array}{l}\text { Amplitude } \\
\text { differences }\end{array}$ & $\begin{array}{l}\text { Seasonalfactor of total tourismependiture } \\
\text { is about } 405.4 \% \text { arger than that of total } \\
\text { tourismnights }\end{array}$ & $\begin{array}{l}\text { Ampitide differences Venezuelan narlet and possibly alo US } \\
\text { naritet (not inchded in the analysis) }\end{array}$ & 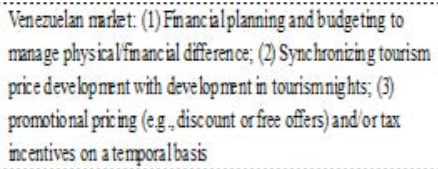 \\
\hline & $\begin{array}{l}\text { Tring } \\
\text { differences }\end{array}$ & $\begin{array}{l}\text { Seasonal factor total tourismerpenditure } \\
\text { hags over that of total tourismn ights by } 1 \\
\text { quarter }\end{array}$ & $\begin{array}{l}\text { Other makets (lag =3); possibly also the US nariat (not } \\
\text { inchded in the analysis) }\end{array}$ & 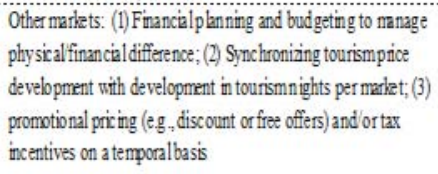 \\
\hline \multirow[t]{3}{*}{$\begin{array}{l}\text { Totalaverage daly ependiture } \\
\text { versus total stay-0ver tourism }\end{array}$} & Comelation & No significant comelation & $\begin{array}{l}\text { Possibly signifiant postive comeation in other markets } \\
\text { cancelling out the neg ative corelations in US and Venemelan } \\
\text { narlets }\end{array}$ & $\begin{array}{l}\text { US, Venezuelan and other makets synchronizing tourismprice } \\
\text { developments with (expected) stay-over tourismdevelopment in } \\
\text { these narlats }\end{array}$ \\
\hline & $\begin{array}{l}\text { Amplitude } \\
\text { differences }\end{array}$ & $\begin{array}{l}\text { Seasonalfactor of totalaverage daily } \\
\text { exenditure is about } 90.8 \% \text { larger than that } \\
\text { of total stay-over tourism }\end{array}$ & 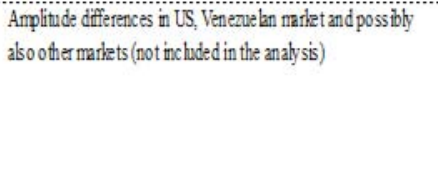 & 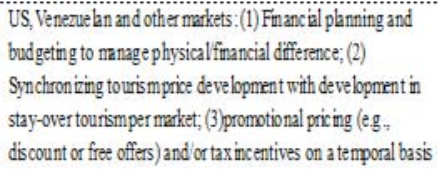 \\
\hline & $\begin{array}{l}\text { Timing } \\
\text { differences }\end{array}$ & $\begin{array}{l}\text { Seasonalfactor total average daily } \\
\text { ependiture lags over that of total stay-over } \\
\text { tourismby } 3 \text { quaters }\end{array}$ & $\begin{array}{l}\text { US (lag }=3 \text { quater), Venezuelan nariet (lag = } 1 \text { quater) and } \\
\text { possibly a bo the other malats (not inchded in the analysis) }\end{array}$ & 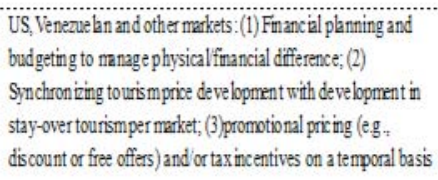 \\
\hline \multirow[t]{3}{*}{$\begin{array}{l}\text { Totalaverage daly ependiture } \\
\text { versus total tourismnights }\end{array}$} & Comelation & Significant positive correlation & $\begin{array}{l}\text { Possibly significant potive correlations in US other makets } \\
\text { (not incuded in the analysis) }\end{array}$ & No spectic action required \\
\hline & $\begin{array}{l}\text { Amplitude } \\
\text { differences }\end{array}$ & $\begin{array}{l}\text { Sessonalfactor of totalaverage daly } \\
\text { ependiture is about } 76.8 \% \text { larger than that } \\
\text { of total tourismnights }\end{array}$ & 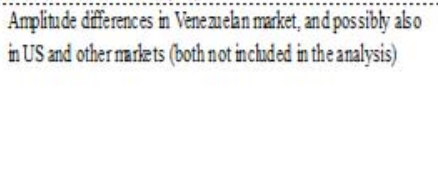 & 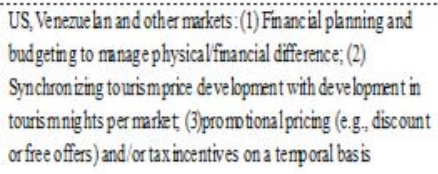 \\
\hline & $\begin{array}{l}\text { Tring } \\
\text { differences }\end{array}$ & $\begin{array}{l}\text { Seasonalfactor total average daly } \\
\text { ependiture lags over that of total tourism } \\
\text { nights by } 2 \text { quarters }\end{array}$ & $\begin{array}{l}\text { Vene zuelan mariket (bg }=3 \text { quanters). A Alo, possible effects by } \\
\text { US and other makkets (both not included in the analysis) }\end{array}$ & 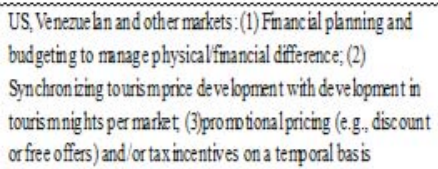 \\
\hline
\end{tabular}




\section{Conclusion}

Seasonality in tourism is more than just a recurring physical aspect. It is both a monetary and a non-monetary matter, and inconsistencies between the seasonal factors of both can produce suboptimal situations, with less best options when formulating and implementing anti-seasonal policies. This study investigated the discrepancies between seasonal factors of monetary and non-monetary indicators of tourism development in Aruba, by analyzing the pattern, amplitude and timing differences. The results show important differences in all three dimensions of analysis when comparing the seasonal factors of both monetary and non-monetary tourism indicators. These results were found to differentiate between timeframe of analysis (1996-2011 versus 20072011), quarter of analysis (first, second, third and fourth quarter), variable of analysis (stay-over tourism, tourism nights, tourism expenditures, average daily expenditures) and market of analysis (US, Venezuela and other markets). The latter differentiation was found to either mitigate or exacerbate the aggregate market results, depending on both the timeframe and quarter being considered.

The findings are important, not only because they shed light into the relation between the seasonal factors of a number of monetary and non-monetary tourism indicators, but also because they have important managerial implications. Firstly, the findings imply a need for strategies to synchronize the seasonal movements in both monetary and non-monetary tourism indicators to mitigate as much as possible the differences between the two types of indicators. These strategies could involve, among others, measures such as synchronizing physical developments with price developments and introducing seasonal taxes and/or promotional prices to allow for a more closely related co-circulation of both types of tourism indicators. Secondly, the findings point towards a more specific approach when it comes to delineating an anti-seasonal policy, which on itself has gained momentum over time (Ashworth \& Thomas, 1999). The specificity has to do with a dynamic system of events that discriminates between quarters, markets and type of indicators. This approach would likely provide better results than a one-size-fits-all policy concept.

Some delimitation may apply to the data involved in this study. Firstly, the published data was available only on a quarterly basis, which hampers an analysis of the seasonal differentiation on a more frequent level of periodicity, for example, on a monthly basis. This inhibits a more indepth level of diversification within the anti-seasonal policy. Access to monthly data could 
strengthen the results. Secondly, the seasonality tests have excluded the variables of US tourism nights and average daily rates of the other markets from further analysis, resulting in the need to make presumptions in the end about possible causality effects involving these two markets. Access to monthly data could perhaps also solve this problem of identifying significant seasonal patterns for these two variables. Thirdly, the US and Venezuelan markets accounted for more than $75 \%$ of the total stay-over tourism in Aruba, and were, therefore, presented separately, while the other markets have remained in an aggregate form in this study to avoid complications in the analysis due to data overflow. The results have suggested a role for the other markets in explaining seasonal differences in the aggregate of both monetary and non-monetary tourism indicators. Additional studies to analyze seasonality in the markets grouped under this heading could strengthen the anti-seasonal policy when it comes to guidelines specifically intended for this group of markets.

Future research should focus on extending this investigation to target the markets incorporated under the other markets category, which could ultimately improve the quality of the anti-seasonal policy. Moreover, this study could be expanded to include other destinations, for example, other Caribbean islands, so to compare the findings with the results in these destinations. This could assist in benchmarking Aruba's tourism performance in terms of seasonality with its competitors. The latter could also benefit the anti-seasonal policy, while it could contribute to the literature on the relationship between the seasonal factors of monetary and non-monetary tourism indicators. 


\section{References}

Ahas, R., Aasa, A., Mark, U., Pae, T., \& Kull, A. (2007). Seasonal Tourism Spaces in Estonia: Case Study with Mobile Positioning Data. Tourism Management, 28(3), 898-910.

Aruba Tourism Authority. (2013). Weather. Retrieved March 9, 2013, from $\mathrm{http} / / / \mathrm{www}$.aruba.com/explorearuba/islandfacts/weather.aspx

Ashworth, J., \& Thomas, B. (1999). Patterns of seasonality in Employment in Tourism in the UK . Applied Economic Letters, 6(11), 735-739.

Bails, D., \& Peppers, L. (1993). Business Fluctuations, Forecasting techniques and Applications. Prentice Hall.

Baron, R. (1975). Seasonality in Tourism, A Guide to the Analysis of Seasonality and Trends for Policy Making. The Economist Intelligence Unit Ltd.

Baum, T., \& Hagen, L. (1999). Responses to Seasonality: the Experiences of Peripheral Destinations. International Journal of Tourism Research, 1(5), 299-312.

Beaulieu, J., \& Miron, J. (1993). Seasonal Unit Roots in Aggregate U.S. Data. Journal of Econometrics, $55,305-328$.

Bender, O., Schymacher, K., \& Stein, D. (2005). Measuring Seasonality in Central Europe's Tourism-how and for what? 10th International Conference on Information \& Communication Technologies (ICT) in Urban Planning and Spatial Development and Impacts of ICT on Physical Space (pp. 303-309). Austria: Competence Center for Urban and Regional Planning.

Bloem, A., Dippelsman, R., \& Maehle, N. (2001). Seasonal Adjustment and Estimation of Trend-Cycles. In International Monetary Fund, Quarterly National Accounts Manual-Concepts, Data Sources, and Compilation (pp. 125-146). International Monetary Fund.

Boffa, F., \& Succurro, M. (2012). The Impact of Search Cost Reduction on Seasonality . Annals of Tourism Research, 39(2), 1176-1198.

Butler, R. (2001). Seasonality in Tourism: Issues and Implications. In T. Baum, \& S. Lundtrop, Seasonality in Tourism (pp. 5-21). Elsevier, Ltd.

Butter, F. d., \& Fase, M. (1988). Seizoensanalyse en beleidsdiagnose. De Nederlandsche Bank, Amsterdam.

Cannas, R. (2012). An Overview of Tourism Seasonality: Key Concepts and Policies. Alma Touism: Journal of Tourism, Culture and Territorial Development, 1(5), 40-58.

Cole, S., \& Razak, V. (2009). How far, and how fast? Population, culture, and carrying capacity in Aruba. Futures, 41, 414-425.

Croce, V., \& Wöber, K. (2010). Seasonality in City Tourism: Concepts and Measurement. In J. Mazanec, \& K. Wöber, Analysing International City Tourism (2nd ed., pp. 59-77). Springer-Verlag.

Croes, H., \& Hooimeijer, P. (2007). Product-marketing mixing: An all-season destination tool. In The Impact of Tourism on the Economy and Polutaion of Small Islands: The Case of Aruba (pp. 3951). Phd. Thesis Utrecht University.

Cuccia, T., \& Rizzo, I. (2011). Tourism Seasonality in Cultural Destinations: Empirical Evidence from Sicily. Tourism Management, 32, 589-595.

De Cantis, S., \& Ferrante, M. (2011). Measurig Seasonality: Performance of Accommodation Establishments in Sicily Through the Analysis of Occupance Rates. In A. Mattias, P. Nijkamp, \& M. Sarmento (Eds.), Tourism Economics, Impact Analysis (pp. 261-280). Springer-Verlag. 
De Cantis, S., Ferrante, M., \& Vaccina, F. (2011). Seasonal Pattern and Amplitude - A Logical Framework to Analyse Seasonality in Tourism: An Application to Bed Occupancy in Sicilian Hotels. Tourism Economics, 17(3), 655-675.

Donatos, G., \& Zairis, P. (1991). Seasonality of Foreign Tourism in the Greek Island of Crete. Annals of Tourism Research, 18(3), 515-519.

Drakatos, C. (1987). Seasonal Concentration of Tourism in Greece. Annals of Tourism Research, 14(4), 582-586.

Dritsakis, N. (2008). Seasonal Analysis of Tourist Revenues: An Empirical Research for Greece. Tourismos: An International Multidisciplinary Journal of Tourism, 3(2), 57-70.

Farooque, G. (2003). Effects of Transformation Choice on Seasonal Adjustmen Diagnostics and Forecast Errors. Retrieved August 20, 2012, from http://www.fcsm.gov/03papers/Farooque.pdf

Fernández-Morales, A. (2003). Decomposing Seasonal Concentration. Annals of Tourism Research, 30(4), 942-956.

Franses, P. (1996). Recent Advances in Modelling Seasonality. Journal of Economic Surveys, 10(3), 299345.

Goh, G. (2012). Exploring the Impact of Climate on Tourism Demand. Annals of Tourism Research, $x x(\mathrm{xx}), 1859-1883$.

Goh, G., \& Law, R. (2002). Modeling and Forecasting Tourism Demand for Arrivals With Stochastic Nonstationary Seasonality and Intervention. Tourism Management, 23(5), 499-510.

Hylleberg, S. (1992). General Introduction. In S. Hylleberg (Ed.), Modeling Seasonality (pp. 3-14). Oxford.

Hylleberg, S., Engle, R., Granger, C., \& Yoo, B. (1990). Seasonal Integration and Cointegration. Journal of Econometrics, 44(1), 215-238.

Jang, S. (2004). Mitigating Tourism Seasonality, A Quantitative Approach. Annals of Tourism Research, 31(4), 819-836.

Karamustafa, K., \& Ulama, S. (2010). Measuring the Seasonality in Tourism With the Comparison of Different Methods. Euromed Journal of Business, 5(2), 191-214.

Koc, E., \& Altinay, G. (2007). An analysis of seasonality in monthly per person tourism spending in Turkish inbound tourism from a market segmentation perspective. Tourism Management, 28, 227-237.

Koenig-Lewis, N., \& Bischoff, E. (2005). Seasonality Research: The State of the Art. International Journal of Tourism Research, 7(4-5), 201-219.

Koenig-Lewis, N., \& Bischoff, E. (2010). Developing Effective Strategies for Tackling Seasonality in the Tourism Industry. Tourism and Hospitality Planning \& Development, 7(4), 395-413.

Kulendran, N., \& Wong, K. (2005). Modeling Seasonality in Tourism Forecasting. 44(2), 163-170.

Lee, C., Bergin-Seers, S., Galloway, G., O'Mahony, B., \& McMurray, A. (2008). Seasonality in the Tourism Industry, Impacts and Strategies.

Lim, C., \& McAleer, M. (2000). Monthly Seasonal Variations, Asian Tourism to Australia. Annals of Tourism Research, 28(1), 68-82.

Lim, C., Chang, C., \& McAleer, M. (2009). Forecasting H(M)otel Guest Nights in New Zealand. International Journal of Hospitality Management, 28(2), 228-235.

Meterorological Department of Atruba. (2013). Climate Data. Retrieved March 9, 2013, from www.meteo.aw 
Pegg, S., Patterson, I., \& Vila Gariddo, P. (2012). The Impact of Seasonality on Tourism and Hospitality Operations in the Alpine Region of New South Wales, Australia. International Journal of Hospitality Management, 31, 659-686.

Ridderstaat, J. (2007). The Lago Story, The Compelling Story of an Oil Company on the Island of Aruba. Editorial Charuba.

Salish, N., \& Rodrigues, M. (2011). Panel Seasonal Unit Root Tests: An Application to Tourism. In A. Matias, P. Nijkamp, \& M. Sarmento (Eds.), Tourism Economics, Impact Analysis (pp. 183-210). Springer-Verlag.

Sharpley, R. (2003). Tourism, Modernisation and Development on the Island of Cyprus: Challenges and Policy Responses. Journal of Sustainable Tourism, 11(2\&3), 246-265.

Song, H., Witt, S., \& Li, G. (2009). The Advanced Econometrics of Tourism Demand. Routledge.

US Bureau of Census. (2010). Seasonal Adjustment Diagnostics, Census Bureau Guidelines. Retrieved February 15, 2013, from http://www.census.gov/ts/papers/G18-0_v1.1_Seasonal_Adjustment.pdf

Vanegas Sr., M., \& Croes, R. (2000). Evaluation of Demand, US Touristst to Aruba. Annals of Tourism Research, 27(4), 946-963.

Vergori, A. (2012). Forecasting Tourism Demand: The Role of Seasonality. Tourism Economics, 18(5), 915-930.

World Travel \& Tourism Council . (2012). Travel \& Tourism, Economic Impact 2012--Aruba.

Yacoumis, J. (1980). Tackling Seasonaility. International Journal of Tourism Management, 1(2), 84-98.

Yu, G., Schwartz, Z., \& Walsh, J. (2009). Effects of Climate Change on the Seasonality of Weather for Tourism in Alaska. Arctic, 62(4), 443-457.

Yu, G., Schwartz, Z., \& Walsh, J. (2010). Climate Change and Tourism Seasonality. Journal of Tourism, VI(2), 51-65. 